NBER WORKING PAPER SERIES

\title{
THE POLITICAL ECONOMY OF MEXICO'S ENTRY TO NAFTA
}

Aaron Tornell

Gerardo Esquivel

Working Paper 5322

\section{NATIONAL BUREAU OF ECONOMIC RESEARCH 1050 Massachusetts Avenue \\ Cambridge, MA 02138 \\ October 1995}

Prepared for the 6th Annual NBER East Asian Seminar on Economics. We thank John Coatsworth, Michael Dooley, Jonathan Fox, Wontack Hong, Takatoshi Ito and John Womack for helpful discussions, and Adrian Ten-Kate and Roberto Bello for providing us with statistical information. We also thank the David Rockefeller Center for Latin American Studies at Harvard University for financial support. Jessica Pepp provided excellent research assistance. This paper is part of NBER's research programs in International Finance and Macroeconomics, and International Trade and Investment. Any opinions expressed are those of the authors and not those of the National Bureau of Economic Research.

() 1995 by Aaron Tornell and Gerardo Esquivel. All rights reserved. Short sections of text, not to exceed two paragraphs, may be quoted without explicit permission provided that full credit, including $(\odot)$ notice, is given to the source. 


\section{THE POLITICAL ECONOMY OF} MEXICO'S ENTRY TO NAFTA

\section{ABSTRACT}

In this paper, we derive three lessons from Mexico's experience. First, deep reforms like trade liberalization are not likely to happen by government decree. Instead, they usually come about when the unanimous blocking of reform by powerful elites breaks down. In the case of Mexico, this happened during a fiscal crisis, when some groups tried to displace other groups in order to capture a greater share of fiscal revenue. Second, in the presence of entrenched elites, the sustainability of reform depends on the existence of new groups that benefit from the new status quo and have enough power to defend it. Thus, the speed of successful reform is determined by the speed with which new groups are consolidated. Initially, Mexico limited radical liberalization to the manufacturing sector. The government has only recently begun to undertake serious liberalization in the services and agriculture sectors. The third lesson we take from Mexico is that the importance of formal agreements like NAFTA lies not so much in the ability of these agreements to reduce average import tariffs among their parties and improve their terms of trade vis $a$ vis the rest of the world, as claimed by the optimal tariff literature, but in that they serve as commitment devices to force reforms to continue.

Aaron Tornell

Department of Economics

Littauer M-6

Harvard University

Cambridge, MA 02138

and NBER
Gerardo Esquivel

Department of Economics

Harvard University

Cambridge, MA 02138 


\section{Introduction}

Typically, Computable General Equilibrium (CGE) models predict that Mexico's gains from NAFTA will be small. This is because Mexico has already opened the manufacturing sector of its economy, and U.S. and Canadian import tariffs are already very low. However, if NAFTA promised only a minimal gain for Mexico, why did President Salinas take such great pains in 1993 and 1994 to ensure that the agreement was signed? Did Mr. Salinas simply ignore facts and knowingly waste political and financial energy on a useless project? We do not think so. We believe that the CGE models analyzing NAFTA's effects have missed an essential element of the agreement: its role as a commitment mechanism. We will argue that the Salinas government's ardent pursuit of NAFTA was motivated by the desire to ensure that necessary future economic and political reforms would be carried out.

To fully understand NAFTA's implications, one should view the agreement not as an isolated event, but as one part of the process of economic liberalization in Mexico. The exploration of this process provides three lessons that can be applied to other cases. First, deep reforms like trade liberalization are not likely to happen by government decree. Instead, they usually come about when the unanimous blocking of reform by powerful elites breaks down. In the case of Mexico, this happened during a fiscal crisis, when some groups tried to displace other groups in order to capture a greater share of fiscal revenue. Second, in the presence of entrenched elites, the sustainability of reform depends on the existence of new groups that benefit from the new status quo and have enough power to defend it. Thus, the speed of successful reform is determined by the speed with which new groups are consolidated. Initially, Mexico limited radical liberalization to the manufacturing sector. The government has only recently begun to undertake serious liberalization in the services and agriculture sectors. The third lesson we take from Mexico is that the importance of formal agreements like NAFTA lies not so much in the ability of these agreements to reduce average import tariffs among their parties and improve their terms of trade vis a vis the rest of the world, as claimed by the optimal tariff literature, but in that they serve as commitment devices to force reforms to continue. 
Let us examine how the Mexican experience illustrates the first lesson. By the late 1960s, it was recognized in Mexico that the country had to abandon the import-substitution development path it, like many other countries, had been following: trade and the economy had to be liberalized (see Ortiz Mena (1970)). No strong steps toward liberalization were taken, however, until the debt and oil crises of the mid-1980s, when trade in manufactures was liberalized. This course of events presents a puzzle that has also arisen in the reform processes of many other countries: why is it that deep reforms tend to take place during bad economic times (the mid1980s for Mexico) but not during more favorable periods, like the oil boom years of the late 1970s, when adjustment costs are more affordable? The explanation we give in this paper is that as fiscal resources plummeted in the eighties, the two powerful elites in the manufacturing sector --the statist elite and the private import-competing elite-- tried to weaken each other in order to gain access to a greater share of fiscal transfers. The statist elite induced expropriations, and the private elite responded by inducing trade liberalization. This move was costly for the private elite in the short run because it forced a reallocation of fixed factors. At the same time, however, trade liberalization weakened the statist elite, as we will explain below. The private elite did not block trade liberalization in the eighties as it had in the seventies because in the eighties its trade-off was not between trade liberalization and the status quo but between trade liberalization and being further expropriated.

Now we consider the second lesson. In order to sustain reform, the Mexican government limited radical liberalization to the manufacturing sector. It did not radically restructure agriculture and services, because alienating all powerful groups in society could have derailed economic reform altogether. Instead, during 1985-94 the government focused its energies on forming new coalitions in the manufacturing sector--a new export elite and a new group of foreign investors--and weakening the statist elite and the old private elite ${ }^{1}$. The government

${ }^{1}$ Throughout this paper we identify a group or elite by the fixed factors it controls, not by the identity or historical background of its members. Thus, when we say that a group was weakened we do not necessarily mean that all persons belonging to that specific group were weakened or impoverished. Instead they may simply have shifted their ownership of fixed factors to other sectors. As a result their interests now lie with a new group. 
accomplished the transformation of the power structure through privatization, deregulation, and the enactment of more friendly foreign investment rules.

Next we explore the third lesson, that NAFTA's greatest importance lies in its use as a commitment device. NAFTA is a commitment by the Mexican government to eliminate protection in agriculture and services within the next fifteen years (the agreement also entails a marginal reduction in protection for the already-liberalized manufacturing sector), in exchange for a decrease in U.S. and Canadian protectionist barriers, and a reduction in the uncertainty associated with trade disputes. A formal agreement like NAFTA is very important for Mexico because radical liberalization of its economy (indeed, of any economy) is bound to have deep political effects. The ability of Mexico's ruling party (the PRI) to capture the agricultural vote has ensured its ability to pursue reforms in the manufacturing sector without major political obstruction. The broader liberalization promised by NAFTA will greatly erode this electoral machine, as it will alienate the agricultural sector. In principle, one could argue that this imminent erosion will threaten the reform in two ways. First, uncertainty about the political future could tempt politicians in the future to delay further liberalization indefinitely. Second, there is the danger that when the PRI's power erodes, new political forces will arise and overturn the reforms. In this paper, however, we argue that the policies implemented by former Presidents de la Madrid and Salinas make it very unlikely that such pessimistic scenarios will unfold. The first scenario is unlikely because NAFTA has already set the liberalization agenda; thus, it is not left to political discretion --this might be the reason Salinas pursued NAFTA so feverishly. The second scenario is unlikely because by the time total trade liberalization has been implemented and the PRI machine has eroded, the new export and foreign investment groups will have consolidated their power and will find it optimal to use their economic resources to ensure that the reforms do not get derailed.

The bailout that the Mexican government received in early 1995 after the financial panic of December 1994 exemplifies the last point. Given that in early 1995 Mexico did not have enough liquidity to repay its dollar-denominated short term debt, a default was likely. This default might have forced the government to follow inward looking policies and increase anew 
the power of traditional elites, risking the derailment of reforms. The network of US firms with investments in Mexico used their political clout to induce an unprecendentedly speedy response from the US government and International Organizations. This support allowed Mexico to repay its short term debt and even to resume borrowing in International markets by mid 1995. Moreover, the Mexican government responded to this crisis with an acceleration of the privatization program and the opening of the financial system.

The set-up of the paper is as follows. In section 2 we trace the evolution of trade protection and the tradable sector in Mexico during the past two decades. In section 3, we examine some effects of trade reforms on the Mexican economy. In section 4 , we present a political economy interpretation of the Mexican reforms and expand on the three lessons discussed above. In section 5 we analyze NAFTA. Finally, we present our conclusions in section 6.

\section{Trade Liberalization}

In 1970 the Mexican economy was very protected. In that year, $65 \%$ of items in Mexico's tariff structure were subject to import permits, and these items accounted for $59 \%$ of the total value of imports. By the late sixties some voices were already calling for a change in this pattern. It was not until the mid-seventies, however, that the Mexican government initiated a mild program of liberalization which substituted ad-valorem tariffs for import permits. But despite these changes, the economy remained basically closed. At last, in 1979, it seemed that trade liberalization would soon be a reality. In that year, President Lopez Portillo announced Mexico's intention to accede to the GATT. A few months later, however, after "consultations," Lopez Portillo announced there would be no accession. Moreover, with the balance of payments problems of the early 1980s, trade barriers were increased again and Mexico became an almost impenetrable economy. By the end of $1982,100 \%$ of imports were subject to permit.

Finally, in 1985, the government announced accession to the GATT as well as a new 
liberalization program. Since then, the opening process has continued without interruption. In 1985 the share of items in the tariff structure subject to import permits was reduced to $12 \%$, and by 1994 the share was only $1 \%$. The opening is also illustrated by the change in the percentage of total value of imports accounted for by imports subject to permits. This share fell from $83 \%$ in 1984 to $35 \%$ in 1985 , and to $10 \%$ in 1994 , as shown in Table 1 .

\subsection{Manufactures}

Liberalization in the manufacturing sector took place very rapidly. In terms of non-tariff protection, about $92 \%$ of domestic production in manufactures was covered by import permits in June 1985 . By the end of that year, less than $50 \%$ of manufactures remained subject to import permits. By 1990 , this indicator dropped to only $11 \%$ leaving only a handful of products still subject to this kind of protection. Figure 1 traces this indicator for various industries between 1985 and 1990 . It shows that by 1990 only the Tobacco industry was substantially protected by an import license requirement, whereas Transportation Equipment and Food industries were mildly covered and in all other sectors protection had been entirely dismantled.

Tariff protection also fell drastically after 1985 . The average tariff rate for manufactured goods fell from $34 \%$ in 1985 to $14 \%$ in 1990 . The industries that suffered the largest tariff reductions were the beverage, glass, apparel, footwear and transportation equipment industries. Figure 2 traces average tariff rates for different industries from 1985 to 1990 . Figures 1 and 2 confirm that the opening process had profound effects on the entire manufacturing industry.

\subsection{Agriculture}

Mexican agriculture is composed of two sectors: a traditional sector and a modern sector. The former remained closed until 1994. The modern sector, on the other hand, has been liberalized since 1987. This sector includes products such as tomatoes, and citrus and tropical fruits. Mexico is highly competitive in the production of these goods. 
In the traditional agricultural sector, the two most important crops are maize and beans. These two products account for as much as $70 \%$ of Mexico's arable land and for about $35 \%$ of its rural employment. Historically, maize and beans have been fiercely protected. Until 1993, maize was subject to import permits and received a governmental support price well above the world market price (Levy and van Wijnbergen (1991) compute a $70 \%$ wedge). The argument for this protection is one of distributional equity: maize is the crop that generates the most rural employment (29\%) and uses the most arable land (42\%). The same argument has been used for the production of beans, which were also subject to import permits until 1993.

Historically, Mexican agriculture has been protected mainly through non-tariff barriers, usually import permits. Figure 3 shows the evolution of the share of agricultural and total output covered by these permits. This figure shows that Agriculture maintained a high degree of nontariff protection until very recently and that this sector was not affected by the first set of liberalization measures enacted in 1985. The reduction in the use of agricultural import permits, which started in 1987 , initially left more than $60 \%$ of agricultural output still covered by import permits. Between 1987 and 1993, this indicator decreased steadily, though it was always above $45 \%$.

On the other hand, tariff protection has played a relatively minor role in the history of the Mexican agricultural sector. Figure 4 shows the evolution of the average tariff for both agriculture and the whole economy between 1985 and 1993. During this period, Agriculture kept a relatively low but constant level of tariff protection.

Figure 5 summarizes the different patterns of liberalization between the agriculture and manufacturing sectors. This figure presents the import penetration rates by sector for the period 1981-1991. The pattern is clearly dual: the import penetration rate in Agriculture remained relatively constant at about $10 \%$, while the same indicator for Manufactures rose constantly from $28 \%$ in 1985 to $59 \%$ in 1991 . 


\section{Effects of Trade Liberalization}

Trade liberalization had a sizeable effect on the volume of trade. Exports increased from $\$ 3$ billion in 1975 to $\$ 34.5$ in 1994 (see Table 2). The increase from 1975 to 1985 is explained by an increase in oil revenues. The increase from 1985 to 1994 , however, is explained by an increase in manufacturing exports. This is illustrated in Figure 6, which charts the evolution of Mexican exports by type of good from 1975 to 1994 . Oil exports reached a peak in 1982-1984 and fell considerably starting in 1986. Manufactured exports began an upward trend in 1985, and by 1994 they were five times what they had been just ten years ago. Their share of total exports grew from $17 \%$ in 1982 to $70 \%$ in 1994.

Imports also increased very rapidly during this period. They grew from $\$ 7$ billion in 1975 to $\$ 59$ billion in 1994 (see Table 2). Figure 7 shows how the composition of imports changed. Consumption and intermediate imports grew relative to capital goods imports. This suggests that producers of consumer goods, which grew during the 1950's and 1960's, have been hurt by trade liberalization.

\subsection{Production}

Trade liberalization induced important transformations within the manufacturing sector. Figures 8a and 8b chart the production volume indices for some industries from 1980 to 1994. Figure $8 \mathrm{a}$ presents the evolution of some of the industries that were hurt by trade liberalization, such as tobacco, textiles, fibers, wood products, furniture, shoes and electrical machinery. Figure $8 \mathrm{~b}$ shows the performance of some of the industries trade liberalization benefited, such as vehicles, engines, auto parts, glass, cement and chemicals. With the exception of vehicles, no "winner" industry seem to have been hurt by the 1982 crisis. The vehicle industry, one of Mexican trade liberalization's biggest success stories, is currently the most important contributor to Mexican manufacturing exports. The adjustment this industry went through in the early eighties allowed it to grow at a very high rate since 1987 --not coincidentally, the first high-tech 
auto plant became operational and exports of vehicles took off during this year (see Berry, Grilli and Lopes-de-Silanes (1993)).

Contrary to popular predictions, trade liberalization did not destroy the Mexican manufacturing industry. Rather, it seems that the industry as a whole adapted relatively easily to the new competition. This is reflected in the composition of Mexican external trade. Esquivel (1992) finds that between 1981 and 1990 the Grubel and Lloyd index of intra-industry trade increased from 28 to 54 across all kinds of goods, and that the same index for manufactured goods rose from 33 in 1981 to 63 in 1990 . Figure 9 traces the evolution of this index for the one-digit categories of the Standard International Trade Classification. Table 4 shows that $72 \%$ of the trade between Mexico and the United States in 1981 was predominantly interindustrial. By 1990, this situation had changed radically: about half the products were traded intraindustrially, accounting for $71 \%$ of foreign trade.

\subsection{Productivity}

Although many studies have been done on the subject, it is still not clear what the impact of trade liberalization on the productivity of the Mexican manufacturing industry has been. Most of the studies have found an overall productivity increase in the industry during the second half of the eighties. Estimates range from 1.1\% per year (Luttmer (1993)) to $5 \%$ per year (Hernandez-Laos (1992)). Clavijo (1992) finds an increase in productivity of about $2.4 \%$ per year, while Tybout and Westbrook (1995) find an increase of $1.8 \%$ per year.

\subsection{Foreign Direct Investment}

Until 1989 Mexico had been reluctant to accept foreign direct investment (FDI) as a major element in its economic development. In 1973, then-President Luis Echeverria enacted a foreign direct investment law entitled "Law to Promote Mexican Investment and Regulate 
Foreign Investment ${ }^{n}$. As the name indicates, this law was more a Mexican-investment-promoting law than a foreign-investment-attracting one ${ }^{2}$. In 1989, the government changed the regulations in an attempt to attract FDI. Specifically, the government lowered the high degree of discretion and removed the $49 \%$ ceiling on foreign capital in several sectors.

Until 1983, with the exception of the peak years of the oil boom, FDI was not very important to the Mexican economy in terms of size, making up only about $10 \%$ of total investment. By 1987, the FDI flow was about twenty times what it had been in the early seventies. At the end of 1993, with the passing of NAFTA by the U.S. Congress, there was a new increase in the flow of FDI to Mexico (see Figures 10 and 11). In fact, the amount of FDI in 1994 was about eight billion dollars, more than twice the average for the 1987-1992 period.

In 1994 the role of FDI in the Mexican economy seems to be more important than ever. During the administration of Carlos Salinas (1988-1994), multinational firms consolidated to form a major player in the economy. FDI's share of Gross Fixed Investment reached its highest ever (30 \%) in 1994, despite the major political difficulties Mexico faced that year. As of September 1993, firms with FDI accounted for $27 \%$ of formal employment in the manufacturing sector and for almost $100 \%$ of employment in the Metallic Products, Machinery and Equipment sector (see SECOFI 1994).

\section{A Political Economy Interpretation of the Mexican Reforms}

NAFTA is just one part of the process of liberalization of the Mexican economy. To fully understand NAFTA, it is necessary to consider the entire sequence of liberalization events which have taken place in Mexico during the last decade. Before presenting our argument we

${ }^{2}$ According to some authors, the immediate effect of the 1973 law was to reduce FDI. Others argue that the negative effects are not obvious and that there is not enough evidence to suggest FDI was reduced. See Peres (1990). 
summarize the main facts (discussed in other sections) that we want to rationalize:

- It had been evident since the late sixties that Mexico had to abandon its import substitution strategy and liberalize trade. However, attempts to liberalize trade and implement a fiscal reform during the seventies were unsuccessful. For instance, in 1979, President Lopez Portillo announced that Mexico would access GATT, but after "consultations" he announced in 1980 that Mexico's economy would remain closed.

- Surprisingly, in the midst of the worst economic crisis since the 1930 s and in the wake of Mexico's most damaging earthquake in this century, President de la Madrid (1982-88) announced Mexico's accession to GATT in 1985. By 1987, trade in manufactures was liberalized.

- Trade liberalization did not destroy the manufacturing sector, although it did induce a strong reallocation within that sector.

- Trade liberalization in manufactures was followed by a tax reform, a radical privatization program, a deregulation program and a structural transformation of the economy during President Salinas's administration (1988-94).

- Also during Salinas' presidency, Mexico made two radical breaks with the past. First, it eased restrictions on foreign investment. Second, it enacted a major constitutional change in land tenure legislation.

- Unlike in manufactures, there was no across the board liberalization of trade in agriculture and services during the Salinas administration.

- During the last part of his presidency Salinas made NAFTA the main policy objective of his administration. His efforts to have Mexico accede to the agreement generated significant political and economic costs. 
- NAFTA is a commitment by Mexico to a future total liberalization of trade in agriculture and services, in exchange for easier access to Mexican goods in the U.S. and Canada.

We will address the following questions about the Mexican reforms. First, we ask why trade liberalization took place in the economically and politically strained environment of the 1980s instead of during the oil boom years when Mexico more easily could have afforded such a reform. Second, why did the Salinas government pursue NAFTA so feverishly? What were the expected gains from accession, given that Mexico had already liberalized trade in manufacturing, US tariff levels were quite small, and NAFTA entailed significant costs? Third, why didn't the government completely open trade in agriculture and services early on, given that this measure would have reduced input prices and made manufactures more competitive?

More generally, we hope to derive broad lessons from the Mexican reform process. In particular, we will address the questions of when trade liberalization is most likely to take place, under which conditions it is most likely to be sustainable, and what the role of a formal agreement like NAFTA is in sustaining a reform process.

\subsection{Historical Background}

Let us first present a brief historical overview to put the Mexican reform process in perspective. The Mexican political system centers on a President who has many formal powers but cannot be reelected, and on an official party (first called PNR, then PMR, and now PRI) which has won every presidential election for the last 60 years. The Mexican president, however, is by no means an all-powerful autocrat, nor is the PRI a monolithic party in which everyone follows the President's instructions. The roots of this political structure can be found in the process of Mexico's state formation. During the 1920s, Mexico was basically in a state of anarchy: several powerful local elites and armies held the only real control over each region. After President-elect Alvaro Obregon was assassinated in 1929, then-President Calles formed 
the PNR as an emergency agreement with powerful groups and local bosses across the country to comply with the formalities of presidential elections (see Meyer (1978)). In several states the existing bosses (caciques) and parties agreed to franchise the PNR name but did not yield any effective power to the central government. The state of Chiapas is a clear example of this.

The process of state formation, which paralleled the formation of the official party, consisted of transforming the independent local armies and power groups of each region into members of a national corporation. In order to induce them to accept this corporatization, the government conferred on these groups monopoly rights over certain industries and/or geographical areas in exchange for loyalty. This consolidation process was enforced by an aggressive industrialization policy centered on import substitution and the undertaking of large infrastructure projects that generated significant rents for these groups. In addition the government granted generous tax exemptions, and implemented favorable wage policies.

President Cardenas (1934-1940) took this corporatization process one step further. First, he implemented an ambitious land reform through the Ejido program. This program gave the right to use land (but not ownership rights) to a vast number of peasants, and absorbed the defeated peasant movements (Zapatistas) into the political corporation, minimizing the risk of future rebellions ${ }^{3}$. Second, the government gained control of the labor movement through the "Confederacion de Trabajadores Mexicanos" (CTM), which is still a pillar of the PRI. Lastly, the military were incorporated into the party (see Hernandez Chavez (1979)).

These policies generated social peace and high growth from the 1940s through the 1960s. A by-product was the entrenchment of powerful rent-seeking groups. By the late sixties one

${ }^{3}$ The ejido is a communal tenure system that prohibits the selling of land. This program limits peasants' access to credit and improvements in production and, in the long run, undermines agricultural productivity. Ultimately, the rural sector was polarized into two sectors, a modern and highly productive agricultural sector with large scale operation and access to exports markets, and a backward sector formed mainly by ejido lands that remained isolated and scarcely linked to the market economy. 
could distinguish two elites in the manufacturing sector: the private import-competing elite and the statist elite. In addition, the regional bosses who controlled the PRI voting machine and distributed government subsidies to the production of agricultural products comprised a rural elite. The statist elite was comprised of networks associated with state-owned enterprises, such as managers, union leaders, and suppliers.

We should clarify that by powerful group or elite we refer to a group of people who control some fixed factors. Throughout the paper we identify a group by the type of fixed factors it controls, not by the names of the people who comprise it. Thus, even if a group is destroyed, its members may remain powerful as part of a new group.

\subsection{Why Did Trade Liberalization Occur?}

We turn now to the puzzle of why trade was not liberalized during the seventies, when it was considered necessary (Ortiz Mena 1970) and when economic conditions could have supported it, but was instead enacted in the midst of the economic crisis of the mid-eighties. As discussed above, the political system in Mexico is such that no President had the autonomy to liberalize trade by decree, since such liberalization implied the dismantling of a major part of the apparatus that generated rents for the strong elites. Therefore, in rationalizing trade liberalization events, we must bear in mind that government actions do not reflect only the will of an all-powerful autocrat, nor are they solely determined by the will of a majority of atomistic voters. In addition to those of the President and the people, the interests of powerful elites exert a major influence over government actions. In all likelihood, all three interests influence most political events. In this paper, however, we will emphasize the role of powerful elites. That is, we will explain the events in Mexico solely as the outcome of a game among powerful elites. We will assume that the president can take action and implement reform only if it is not blocked by powerful local elites.

As mentioned above, in the 1960s, 1970s and 1980s, there were two strong groups within 
the Mexican manufacturing sector: the private import-competing elite and the statist elite. The political process guaranteed both elites almost unlimited access to fiscal revenue. They enjoyed subsidized inputs and profited from convoluted regulations and strict trade barriers, which increased the profitability of the fixed factors they owned. So why didn't these manufacturing sector elites unanimously block trade liberalization in the economically strained eighties as they had done during the seventies boom? The argument by Tornell (1995) addresses this issue--the following is a summary of that argument.

To understand the process that led to trade liberalization, think of both the private import-competing elite and the statist elite as interacting in a preemption game. At every instant, each group has the opportunity to eliminate the other group's power by incurring a once-and-forall cost. The group that incurs this cost becomes the "leader" and attains the power to monopolize fiscal transfers in the future. The other group becomes the "follower" and loses all access to future fiscal transfers. If both groups incur the cost simultaneously, i.e. if they "match", both see their power to extract fiscal revenue diminished, but neither one loses relative to the other. The cohabitation equilibrium that sustains the status quo breaks down when the payoff of becoming the leader exceeds the payoff of maintaining the status quo. Moreover, if the payoff of matching is greater than the payoff of following, then both groups weaken each other. In this case the government becomes relatively autonomous, and is not beholden to elites anymore. Therefore, it becomes free to implement a reform.

But when does the payoff of becoming the leader exceed the payoff of remaining in the status quo? To address this issue we note that all payoffs are functions of the fiscal revenue available for redistribution. As fiscal revenue declines, the marginal utility of gaining a greater share of it increases. Thus the payoff of leading increases relative to the payoff of remaining in the status quo and the payoff of matching increases relative to following. For a sufficiently big decline in fiscal revenue the payoff of leading becomes greater than the payoff of the status quo, and the payoff of matching becomes greater than the payoff of following. As a result each group tries to displace the other in order to get a greater share of the lower fiscal revenue. Hence, when fiscal revenue is low, the status quo collapses and the potential for reform exists. 
Now we apply this argument to the Mexican experience of the 1970s and 1980s. After the students' riot of 1968 the government of President Echeverria (1970-76) tried to reestablish legitimacy and assuage demands for a reduction in poverty and income inequality by expanding public investment. This expansion significantly strengthened the statist elite. Although Echeverria had a strong anti-business rhetoric, he did not take any measure to reduce the rents received by the private import-substituting elite. For instance, in 1971 he tried to implement a tax reform to increase tax revenues, which made up $8 \%$ of GDP, but he soon abandoned that move. Also, in 1973 Echeverria enacted a law that limited foreign investment, benefiting the private elite.

Echeverria's anti-business rhetoric created a strain between the government and the private sector. President Lopez Portillo, elected in 1976, set out to relieve this strain. After the 1977 discovery of significant oil reserves, and after the price of oil had increased, the government enacted a free-for-all fiscal policy which benefited both elites. The increase in fiscal transfers showed up in the form of an increase in government expenditures, from $10 \%$ of GDP in 1970 to $22 \%$ in 1982. An example of increased transfers to the private sector was the 1981 half-billion-dollar bailout of Grupo Alfa, the biggest private company in Mexico at the time. Other specific actions funded by the expansion included the acceleration of the investment program in government-owned enterprises, the subsidization of oil, gas and electricity prices, and the establishment of an ambitious anti-poverty program, the Mexican Alimentary System (SAM). SAM, which supported grain production and was intended to benefit the poorest citizens of Mexico, provided subsidies that were mostly captured by the rural elite (Fox 1992). Lopez Portillo's expansionary policies caused the fiscal deficit to jump from 10\% of GDP in 1977 to $17 \%$ in 1982.

During the 1970s, fiscal revenue remained high enough to finance all this additional government spending. Government subsidies increased the profitability of fixed factors owned by the statist elite and the private import-substituting elite. The elites were satisfied with the transfers they were receiving, so no powerful group had an incentive to push for the structural reforms that were needed. During the boom years of the 1970s, no group found that the benefit of ensuring itself a large share of future fiscal revenue outweighed the short-run costs of 
weakening the other groups. Therefore, all powerful elites unanimously blocked reform during those years.

During the eighties, falling oil prices and an interruption in foreign lending forced cutbacks in Mexico's generous government transfer programs--fiscal revenue could no longer cover the demands of all interest groups. This reduction in the size of the pie increased the marginal utility of gaining a greater share of it, and increased the payoff of becoming the "leader" (recall the preemption game discussed above).

The statist elite made the first move, inducing the government to expropriate all Mexican private banks. The banks channeled much fiscal revenue to the private sector (through subsidized credit and implicit guarantees of their borrowings from foreign banks), and their owners comprised one of the strongest groups in the private elite. Lopez Portillo announced the banks' expropriation in September 1982, three months before he left office, in a dramatic address to Congress during which he cried over his failure to help the poor. Simultaneously with the expropriation of the banks, capital controls were imposed and Miguel Mancera, orthodox governor of Mexico's Central Bank, resigned. The private sector responded to these blows by announcing that a national strike would take place on September 8, but representatives canceled the strike a few days later ${ }^{4}$.

The private import-competing elite matched the statist elite's first move. Aware that trade liberalization would be a mechanism by which they could destroy the power of the statist elite, the private elite did not oppose trade liberalization in the 1980s as it had in the 1970s. This time, the private elite's choice was not between trade liberalization and the protectionist status quo, but between trade liberalization and becoming the follower, which would mean being further expropriated by the statist elite. When President de la Madrid took office in December 1982,

${ }^{4}$ It has been argued that the banks' expropriation was really a bailout. Indeed, the banking system was insolvent and the government took over all its liabilities. However, the point we want to stress in this paper is that the bankers lost the "right" to operate banks and thus lost access to future bailouts, as well as the right to obtain other types of fiscal transfers. 
members of the private elite feared that under his tenure expropriations would continue and statism would increase--after all, he had been Minister of Budget and Planning under Lopez Portillo, and had budgeted the massive increase in investment in state owned enterprises. Moreover, de la Madrid assumed the Presidency before the Thatcher and Reagan revolutions repopularized free market policies.

Trade liberalization has been painful for the private sector in that it has forced many firms into bankruptcy and has forced fixed factors to be reallocated, both of which have generated short-run adjustment costs. In addition, the private elite has lost the rents from protection it received before liberalization. Because of reallocation, it has also suffered from the loss of political power associated with the ownership of fixed factors in well-established industries. The extent of these reallocation costs was illustrated in the previous section.

Despite these drawbacks for the private elite, trade liberalization could drastically reduce the power of the statist elite to further expropriate the private elite and extract fiscal subsidies. This would occur through three channels. First, free trade will create new powerful groups of exporters and foreign investors with incentives to defend the new status quo. Thus, an expropriation would not only draw opposition from those new export groups, but also from foreigners. Since the potential cost of confronting powerful foreign firms will be high, it is unlikely that the government will engage in further expropriations. Second, free trade abolished the complex system of import licensing and multiple tariffs, replacing it with one or two rates that apply across the board. This more transparent system quickly highlights rent-seeking behavior, allowing other groups to block such behavior right away. Lastly, agreements signed by a country as part of trade liberalization (such as GATT and NAFTA) impose limits on the extent of subsidization to specific industries and rent-generating regulations that a government can impose.

Ultimately, both elites became weaker and worse-off after the expropriation of the banks and trade liberalization. It is important to note that there was no uncertainty beforehand that this would happen. Both groups induced this outcome because, as a result of decreased government 
revenue in the early 1980 s, the payoff of unilaterally deviating from the status quo at that time by trying to become the leader exceeded the payoff of maintaining the status quo. Note that Coase Theorem does not apply in this case because there is no third party with the power to enforce an agreement between two elites.

\subsection{Reform of the State}

Once both groups in the manufacturing sector weakened each other, the de la Madrid and Salinas governments attained "relative autonomy." They used this autonomy to implement a tax reform, a radical privatization program, and a deregulation program that eliminated many privileges and monopolies conferred during the consolidating years of the PRI.

The puzzling point we wish to highlight and the one we will try to rationalize is that these governments did not fully liberalize agriculture and services. From an economic standpoint, this is an incongruity. If a government's objective is to promote manufactured exports, the right policy is to liberalize agriculture and services. Liberalizing agriculture would free unskilled labor and reduce unskilled wages. Liberalizing services would reduce interest rates, transport costs, and communication costs. Since unskilled labor and services are inputs in the manufacture of exports, the government would certainly promote exports by liberalizing agriculture and services, thereby driving down the costs of these inputs.

Why did the two governments choose not to follow such obviously advantageous policies? Our next point is that the decision not to open trade in agriculture and services fully was necessary to ensure that the reform process would not be derailed. Reformers needed two things to continue pursuing reform. First, they had to be reelected, which could be difficult given that initially the reform did not have much support in the population. Second, they had to avoid alienating all powerful groups simultaneously. With respect to the first requirement, reelection, the reformers depended heavily on the rural vote in the 1988 and 1994 presidential elections, because reforms in the manufacturing sector had damaged the urban electoral machine, and 
elections in urban areas had become more contested. With respect to the second requirement, delaying liberalization of agriculture and services allowed the government to avoid alienating all powerful elites simultaneously, while building new elites to support the new strategy of export promotion and private property.

Let us elaborate on the first requirement, the issue of reelection. A few months before the presidential elections of 1988 , some members of the statist elite who had split from the PRI combined with leftist parties to form the Partido de la Revolucion Democratica (PRD) and captured a third of the vote. Also, the private elite increased its involvement in politics following the 1982 expropriation of the banks. This involvement broke the private elite's implicit agreement with the government by which the private elite stayed out of politics, and the government in turn ensured a profitable investment climate (see Maxfield and Anzaldua (1987)). As a result, elections in urban areas became more contested. Therefore, the PRI has had to rely more on the rural electoral machine to win presidential elections. For instance, Salinas, who received $50.5 \%$ of the total vote, won only $34 \%$ of the votes in "very urban" areas, while he received $77 \%$ in "very rural" areas (see Fox, 1994). The rural electoral machine is closely linked to the network that administers protection to the agricultural sector. Opening trade in agriculture and thus dismantling this protectionist network might have destroyed the rural machine, and with it the presidential hopes of reformers like Salinas and Zedillo.

To expand on the second requirement above, one can view the second part of the de la Madrid administration and the Salinas administration as having been devoted to creating new elites that would support the export promotion and private property strategy. Two new elites were formed under these administrations: the private export elite and the foreign investors elite. Deregulation, privatization and new rules for foreign investment were used as instruments in promoting these elites. Deregulation eliminated the convoluted rules that allowed some groups to enjoy monopoly rents (on this see Fernandez 1995). Through privatization, the government transferred to the new private elite virtually all the firms in the manufacturing sector, with the exception of the energy sector. Through less discretionary rules the government attracted a significantly greater amount of FDI than it had historically. These actions further weakened both 
the statist elite and the old private import-competing elite.

Several investors who had not been in the big leagues during the 1970s and 1980s were able to acquire government assets which transformed them into what one might call "new strong groups." The steel industry illustrates this point. Before privatization there was only one private integrated steel producer in Mexico--Hylsa (a subsidiary of Alfa, beneficiary of the 1981 bailout discussed above). After the privatization of the steel sector, the relative power of Alfa diminished drastically--now it is only one among five major steel producers. The others are: GAN, a consortium of a former pharmaceutical group, a small mining group, and a Dutch steel producer; IMSA, a group of former medium-sized steel processors; ISPAT, a group from India; and Villacero, a group of former medium-sized steel traders. It is interesting to note that as a response to the increased competition induced by privatization, Alfa recently opened a new steel plant which is internationally competitive. Prior to privatization, it is likely that Alfa would simply have sought more protection and received it, threatening to close down if it did not. Today, shutdown threats from a single steel producer could not effectively induce protection because other domestic producers are available to fill the employment and production gap a shutdown would create.

Another indicator of the dilution of power within the private elite that Salinas' reforms have brought about is the increased number of Mexican billionaires. According to Forbes Magazine, there was only one billionaire family in Mexico in the late 1980s--the Garza Sada family, Alfa's major shareholder. In 1994, there were 24 Mexican billionaires, according to Forbes. Outstanding examples are Mr. Roberto Gonzalez, Mr. Carlos Slim, and Mr. Salinas Pliego. Mr. Gonzalez developed the market for tortilla flour and is the biggest producer of tortillas in the US. In the recent privatization of the banks he acquired Banorte. Mr. Slim controls Telefonos de Mexico, the telephone monopoly, in association with Southwestern Bell and France Telecom. Mr. Salinas Pliego is the top Mexican retailer of household appliances. He recently bought from the government Television Azteca and has a joint venture with NBC, which makes him the only private competitor of Televisa, Mexico's other television network. It is worth noting that ten years ago none of these families were billionaires--they did not even rank 
among the country's richest.

We should clarify that the new elite was not formed totally by newcomers: in fact, many of its members had familial or historical links to the old elite. The important point is that the new group is defined not by the historical background of its members, but by their interest in defending the new set of property rights. This common interest is in turn determined by the fact that they own and control fixed factors whose profitability depends on exports.

Summing up, the policies followed by the government during the period 1985-1994 (trade liberalization, deregulation, opening to foreign direct investment and privatization) had the effect of weakening the statist elite and the private import-competing elite, and inducing the formation of two "new powerful groups": the export elite and foreign investors. Since these new elites will benefit from the new set of property rights that have been imposed, once their power is consolidated in the near future they should expend resources to ensure these property rights are maintained.

We should emphasize that the Executive has played a critical role in this process as a coalition builder, not as an authoritarian central planner. This does not mean that the administrations of de la Madrid and Salinas did not push hard for unpopular policies designed to establish the new property rights regime that would support an efficient export economy. Important examples of their efforts in this direction are the tax reform, the privatization program, and the deregulation program.

\section{NAFTA}

As we will describe in section 5.2, most CGE models predict gains for Mexico from NAFTA on the order of 1 to $3 \%$ of steady state GDP. When capital inflows are allowed, possible gains increase to $5-8 \%$. Would even an $8 \%$ increase in steady state GDP be worth the sizable costs President Salinas was willing to incur to ensure NAFTA's approval by the US 
Congress? The answer is probably no. We think that CGE models' predictions fail to capture all the benefits derived from the role of NAFTA as a commitment device, and therefore tend to underestimate the benefits of NAFTA.

As we will describe in section 5.1, trade liberalization in services and agriculture will not be immediate, but will happen gradually over the next ten to fifteen years. This gradual liberalization will be a blow to the elite associated with traditional agriculture, which derives its power from the distribution of subsidies to inefficient producers. This is a serious concern because the PRI vote comes largely from rural voters, and to a great extent, the agricultural elite controls the machine that produces this vote. Thus, trade liberalization will destroy an important part of the PRI voting machine over the next decade. This creates a good deal of uncertainty about who will gain power in the future. The Chiapas uprising on January 1st. 1994, the day on which NAFTA was enacted, symbolizes this uncertainty. Regardless of whether the uprising originated in the peasantry or was induced by an elite that opposes trade liberalization, it proved that there are opponents to the new regime (see de Hinestrosa and Tornell (1994)).

The uncertainty regarding who will get political control once the PRI's agricultural voting machine is weakened will make it politically expedient to delay indefinitely further liberalization or derail reform altogether. Our point is that NAFTA is the commitment device that will ensure that such delay will not occur and reform will continue. This will happen in two ways. First, there are huge political and economic costs associated with breaching an international agreement such as NAFTA. Second, NAFTA will consolidate the power of the new export groups that will have in their interest to defend the new set of property rights.

NAFTA will benefit and strengthen the new Mexican export elite for two reasons. First, it will facilitate the establishment of links with foreign firms interested in the maintenance of policies that support free trade. Second, it will allow the Mexican export sector to grow faster and become a bigger player in the domestic arena. NAFTA will achieve this outcome by reducing the uncertainty generated by trade disputes and by facilitating U.S. and Canadian access to Mexican goods. Also, NAFTA will reduce the cost of inputs, making Mexican exports more 
competitive. Liberalizing trade in agriculture will increase the supply of unskilled labor, thus reducing the real wages of unskilled workers (Venables and Van Wijnbergen, 1993)); liberalizing trade in services will reduce interest rates, transport costs and communication costs.

By the time the reforms stipulated by NAFTA take effect, the new export groups already should have consolidated their power. Thus, they should be able to defend the new status quo, ensuring that reform is not derailed in the transition. The new groups will be able to defend the new status quo in several ways. For instance, they could finance the campaigns of politicians who favor the status quo as opposed to expropriation and inward-looking policies. Also, should the government in place try to renege on reforms, they could finance opposition groups . Thus, regardless of what parties form and win elections in the future, they will find it costly to alter the development path established by the de la Madrid-Salinas regime. Thus, once the new groups will have consolidated their power, the probability of derailment will be very small.

The bailout that the Mexican government received in early 1995 after the financial panic of December 1994 exemplifies this point. Given that in early 1995 Mexico did not have enough liquidity to repay its dollar-denominated short term debt, a default was likely. ${ }^{5}$ This default might have forced the government to follow inward looking policies and increase anew the power of traditional elites, risking the derailment of reforms. The network of US firms with investments in Mexico used their political clout to induce an unprecendentedly speedy response from the US government and International Organizations. Within a few weeks approximately fifty billion dollars in credit lines and loan guarantees was lined up. This support allowed Mexico to repay its short term debt and even to resume borrowing in International markets by mid 1995. Moreover, the Mexican government responded to this crisis with an acceleration of the privatization program and the opening of the financial system. The fact that the U.S. network used its power to save Mexico from a reform-endangering situation suggests that Salinas was successful in inducing the creation of groups that would defend the reforms begun by de la Madrid.

${ }^{5}$ For an analysis of the Mexican crisis of 1994, see Sachs, Tornell and Velasco (1995). 


\subsection{What is NAFTA?}

When NAFTA was enacted on January 1, 1994, tariffs for about half of all import categories were eliminated immediately. Most of the remaining tariffs will disappear within a period of 5 years and only a few of them will remain in effect for a maximum period of 15 years. In 1993, the average Mexican tariff was about $10 \%$ while the average U.S. tariff was about $4 \%$. Therefore, in terms of tariff reduction, the expected changes are relatively small and the bulk of the reductions will be in tariffs on Mexican imports. Still, NAFTA includes restrictions that will reduce the impact of tariff reduction on Mexican products. These measures are aimed at compensating Mexico for the obvious asymmetry in level of development among the three countries involved.

\section{Agriculture}

Agriculture is heavily protected in all three countries. But, while farmers are a very small fraction of the U.S. and Canadian labor forces (3\% in the U.S. and less than $5 \%$ in Canada), as much as $26 \%$ of the Mexican labor force is dependent on agriculture. This suggests that the Mexican economy will face very significant adjustment problems as a result of NAFTA. In those cases where import licenses were still present, they were substituted for ad-valorem tariffs. For instance, tariff protection on corn, wheat and beans, will be phased out over a period of 10 to 15 years.

Textiles

Quota restrictions on Mexican textile imports from the U.S. will be removed gradually over a 10-year period. In this sector the rules of origin will play a very important role in deciding which exports are eligible to be traded.

\section{Automobiles}

In the automobile sector, Mexico will immediately eliminate its tariffs on light trucks and reduce by $50 \%$ tariffs on passenger cars. The remaining tariffs will be phased out over a period 
of 10 years. In this sector, rules of origin were negotiated such that a minimum $62.5 \%$ NorthAmerican parts and labor content will be required for access to the benefits from the Agreement (compared to the $50 \%$ requirement from the Canada-U.S. agreement). Importing used cars from the U.S. into Mexico will be allowed in 10 years.

\section{Financial Sector}

Initially there will be some restrictions on the financial sector in Mexico. Individual firms will face a cap of $1.5 \%$ of the market and, on the aggregate, Canadian and US financial firms will face a ceiling of $8 \%$. This aggregate cap will gradually increase until the year 2000 , after which most of the restrictions will disappear, unless foreign firms have more than $25 \%$ of the market and the Mexican government decides to apply some restrictions.

\section{Side Agreements}

The Free Trade Commission was established by NAFTA to supervise its implementation and to resolve disputes about its interpretation. In addition, there will be binational panels for the resolution of Antidumping and Countervailing Duty determinations. These side agreements will further reduce uncertainty in trade relationships among the three countries involved, which from the Mexican standpoint is one of the most important issues.

NAFTA does not entail either free labor mobility or environmental harmonization requirements. There are, however, supplemental agreements on labor and environmental cooperation, as well as about the establishment of a North American Development Bank. The two supplemental agreements establish that each country will have the right to determine its own regulations, but must commit itself to ensuring their correct implementation.

\subsection{Computable General Equilibrium Models of NAFTA}

The basic conclusion of CGE models is that NAFTA will have small welfare effects. These models suggest this because for the most part they do not include the effects on foreign 
investment and because import tariffs in Mexico (at least in the manufacturing sector) have already experienced a steep decline, because a structural transformation has already occurred (between 1987 and 1993) in Mexico, and because tariff rates in the U.S. and Canada are already low. Here we summarize the results of these models.

According to Brown (1992), these models can be grouped in three categories: static models with constant returns to scale technology and perfectly competitive good markets, static models with increasing returns to scale, and dynamic models. In the first set of models the predicted effects are as follows. If there were a removal of tariffs only, Mexico's real income would increase by $0.11 \%$. If the agreement would include non-tariff-barriers reduction, the predicted gain would vary between $0.3 \%$ and $2.28 \%$. If, in addition, we allow for an increase in capital inflows, Mexico's real income could increase between $4.6 \%$ and $6.4 \%$ ( or $6.8 \%$ if we also allow for endogenous migration). Most of these models also predict an increase in the trade deficit with both the United States and the rest of the world. The predicted effects range from an increase of $0.33 \%$ to $1.49 \%$ in no capital inflows are considered. In the case of capital inflows, the predicted increase is $6.6 \%$.

The second set of models allows for increasing returns to scale and therefore a nonperfectly competitive market structure. Its predictions are similar to those of the first set: predicted effects on Mexican real income range from 1.6 to 3.3\% depending on the market structure, and are as much as $5 \%$ if capital inflows are allowed. Predicted effects on employment are bimodal: some models predict effects ranging from 1.7 to $2.4 \%$; others predict an increase between 5.1 and $5.8 \%$.

Finally, the last group of models predicts gains for Mexico ranging from 0.6 to $2.6 \%$. When there is a reduction in the interest rate (as a result of a lower degree of uncertainty) from 10 to $7.5 \%$, these model predict gains for Mexico as high as $8.1 \%$ of steady state real income.

\section{Conclusions}


In retrospect, the sequence of reform policies adopted in Mexico is fascinating. Neither step resulted from the decree of an all-powerful autocrat, and each step both had the support of a powerful group and generated new powerful groups that would support further reforms.

The first step was to liberalize trade in manufactures. The government undertook this action not as soon as it realized its necessity, but only when the unanimity of the powerful groups within the manufacturing sector broke down in the 1980s. The second step was to consolidate the power of emerging elites with an interest in export promotion, an objective which the government achieved through privatization and deregulation. The third step in the sequence was the signing of NAFTA, and the fourth step will be to actually dismantle protection in the agriculture and services sectors.

The trade liberalization process was not a historically predetermined outcome, but was brought about largely through the decisive contributions of Presidents de la Madrid and Salinas. De la Madrid recognized the window of opportunity created by the economic hardships of the mid-eighties, and began liberalization at the start of his administration. He also recognized the limitations of this opportunity and did not try to liberalize the entire economy. Salinas consolidated the power of the new export group and, by signing NAFTA, committed Mexico to total liberalization in 15 years.

Chances are that if all these steps had been taken at once, Mexico's powerful groups would have colluded and blocked the reform. We can see this from the Venezuelan experience, an interesting contrast to the Mexican one. In 1989-92, Venezuelan President Carlos Andres Perez tried to implement many reforms simultaneously. All the powerful groups in the population opposed him, forcing him to resign. Moreover, his successor, President Caldera, backtracked on many of Perez's reforms.

NAFTA should be understood as a commitment device which guarantees there will be no delays in the continuing reform process. This commitment device, combined with the influence of the new elites that benefit from export promotion, greatly increases the likelihood 
that trade liberalization in Mexico will not be derailed.

$-28-$ 


\section{References}

Berry, S., V. Grilli and F. Lopes-de-Silanes, 1993, "The Automobile Industry and the MexicoUS Free Trade Agreement," in The Mexico-US Free Trade Agreement. Cambridge, MA. MIT Press.

Brown, D., 1992, "The Impact of a North American Free Trade Area: Applied General Equilibrium Models," in North American Free Trade: Assessing the Impact, ed. N. Lusting, B. Bosworth and R.Z. Lawrence. Washington, D.C. The Brookings Institution.

Clavijo, F., 1992, "La Efficiencia Productiva del Sector Manufacturero Mexicano, 1985-1990," mimeo, Mexico: Office of Economic Advisors to the President.

Esquivel, G., 1992, "Comercio Intraindustrial Mexico-Estados Unidos, 1981-1990. " Estudios Economicos, no. 13. Mexico City. El Colegio de Mexico.

Fernandez, A., 1995, "Deregulation as a Source of Growth in Mexico, " in Reform, Recovery and Growth, eds. R. Dornbusch and S. Edwards. Chicago. NBER.

Fox, J., 1992., The Politics of Food in Mexico. Ithaca, NY. Cornell University Press.

Fox, J., 1994., "Political Change in Mexico's New Peasant Economy," in The Politics of Economic Restructuring, ed. Cook et.al. Center for US-Mexican Studies. San Diego: University of California.

Hernandez-Chavez, A., 1979, La Mecanica Cardenista. Historia de la Revolucion Mexicana, vol. 16. El Colegio de Mexico, Mexico.

Hernandez-Laos, E., 1992, "Evolucion de la Productividad Total de los Factores en la Economia Mexicana," mimeo. 
Hinestrosa, P. and A. Tornell, 1994, "Las Condiciones Economicas Como Factor de Descontento Social: El Caso de Chiapas," in Maria Luisa Armendariz ed. Chiapas: Una Radiografia. Mexico: Fondo de Cultura Economica.

Levy, S. and S. van Wijnbergen, 1991, "Maize in the Mexico-United States Free Trade Agreement." Washington, D.C. The World Bank.

Luttmer, E., 1993, "Productivity in Mexican Manufacturing Industries," mimeo, The World Bank.

Maxfield, S. and R. Anzaldua, eds., 1987, Government and Private Sector in Contemporary Mexico. San Diego: University of California.

Meyer, L., 1978, Los Inicios de la Institucionalizacion: La Politica del Maximato, in Historia de la Revolucion Mexicana, vol. 12. El Colegio de Mexico, Mexico.

Ortiz Mena, A., 1970, "El Desarrollo Estabilizador." El Trimestre Economico, no. 146.

Peres, W., 1990, Foreign Direct Investment and Industrial Development in Mexico. Paris: OECD.

SECOFI, 1994, Resultados de la Nueva Politica de Inversion Extranjera en Mexico, 1989-1994. Mexico City. Miguel Angel Porrua Editorial.

Sachs, J, A. Tornell and A. Velsco, 1995, "The Collapse of the Mexican Peso: What Have We Learned?" NBER Working paper 5142.

Tornell, A., 1995, "Are Economic Crises Necessary for Trade Liberalization and Fiscal Reform? The Mexican Experience," in Reform, Recovery and Growth, ed. R. Dornbusch and S. Edwards. Chicago University Press. 
Tybout, J.R. and M.D. Westbrook, 1995, "Trade Liberalization and the Dimension of Efficiency Change in Mexican Manufacturing Industries." Journal of International Economics.

Venables, A. and S. Van Wijnbergen, 1993, "Location Choice, Market Structure and Barriers to Trade: Foreign Investment and the North American Free Trade Agreement," mimeo, The World Bank. 
Figure 1

Output Protected by Import Permits (percentage)

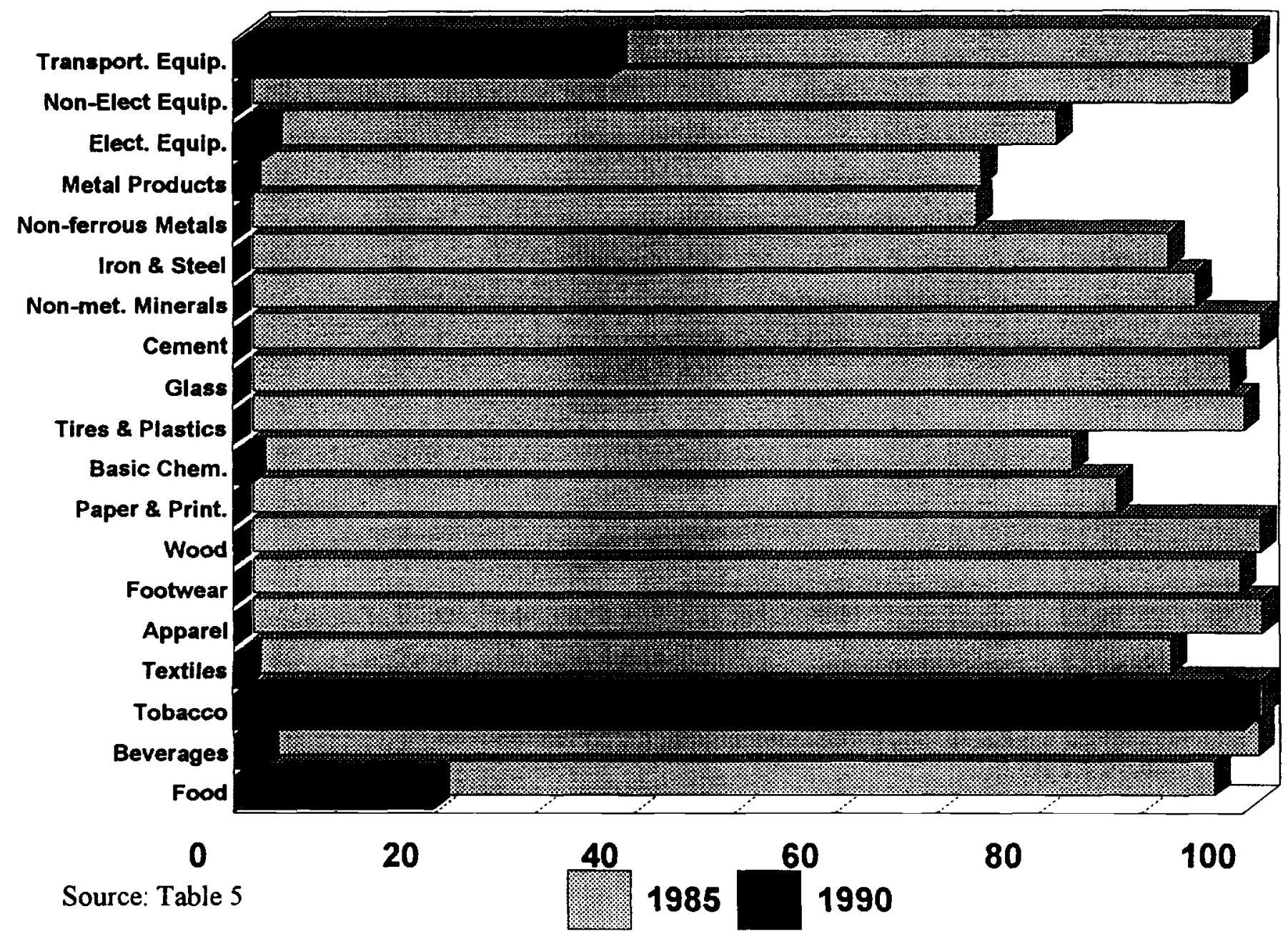


Figure 2

Average Tariff Rates (percentage)

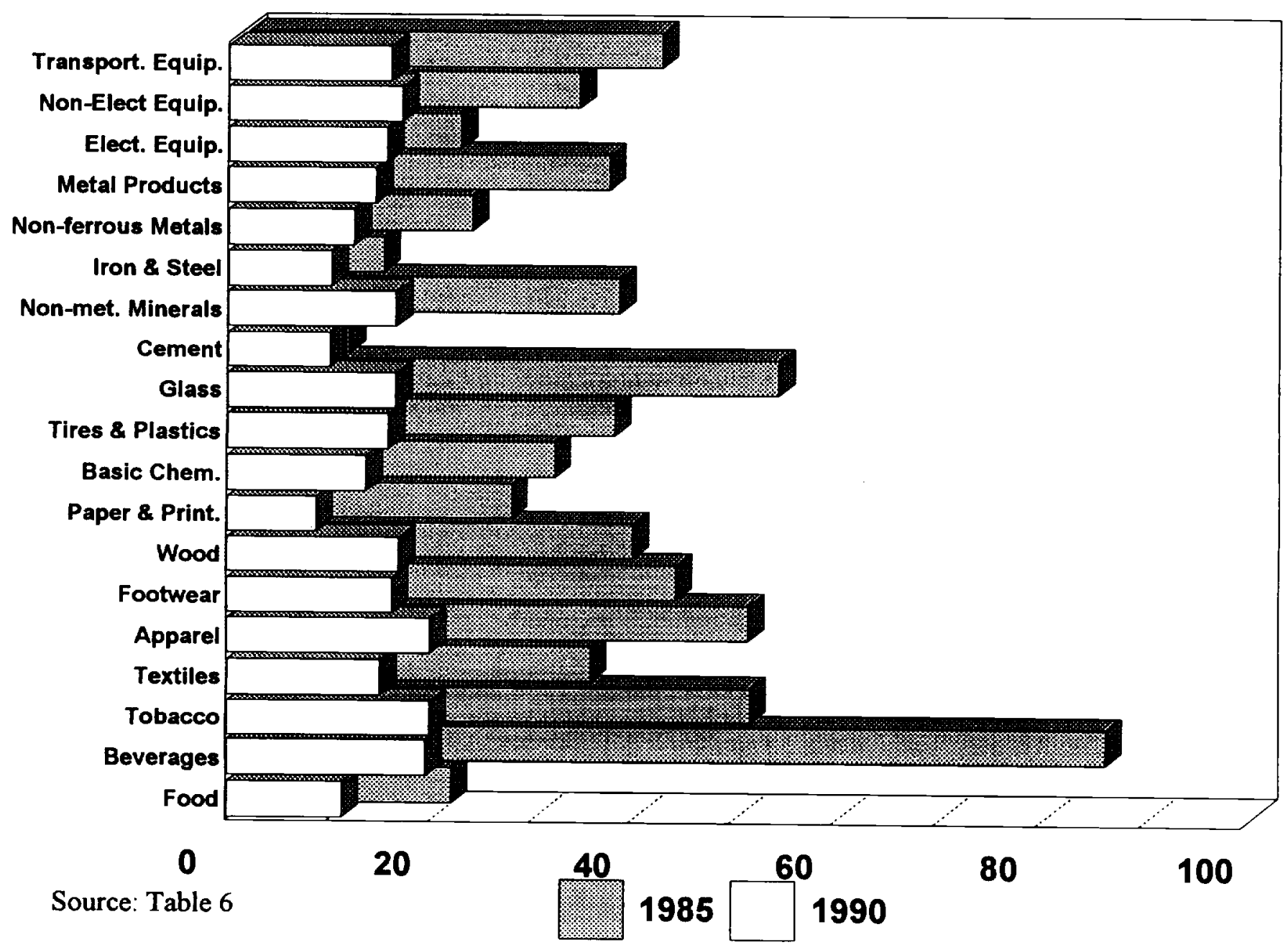


Figure 3 Output Covered by Import Permits

(percentage)

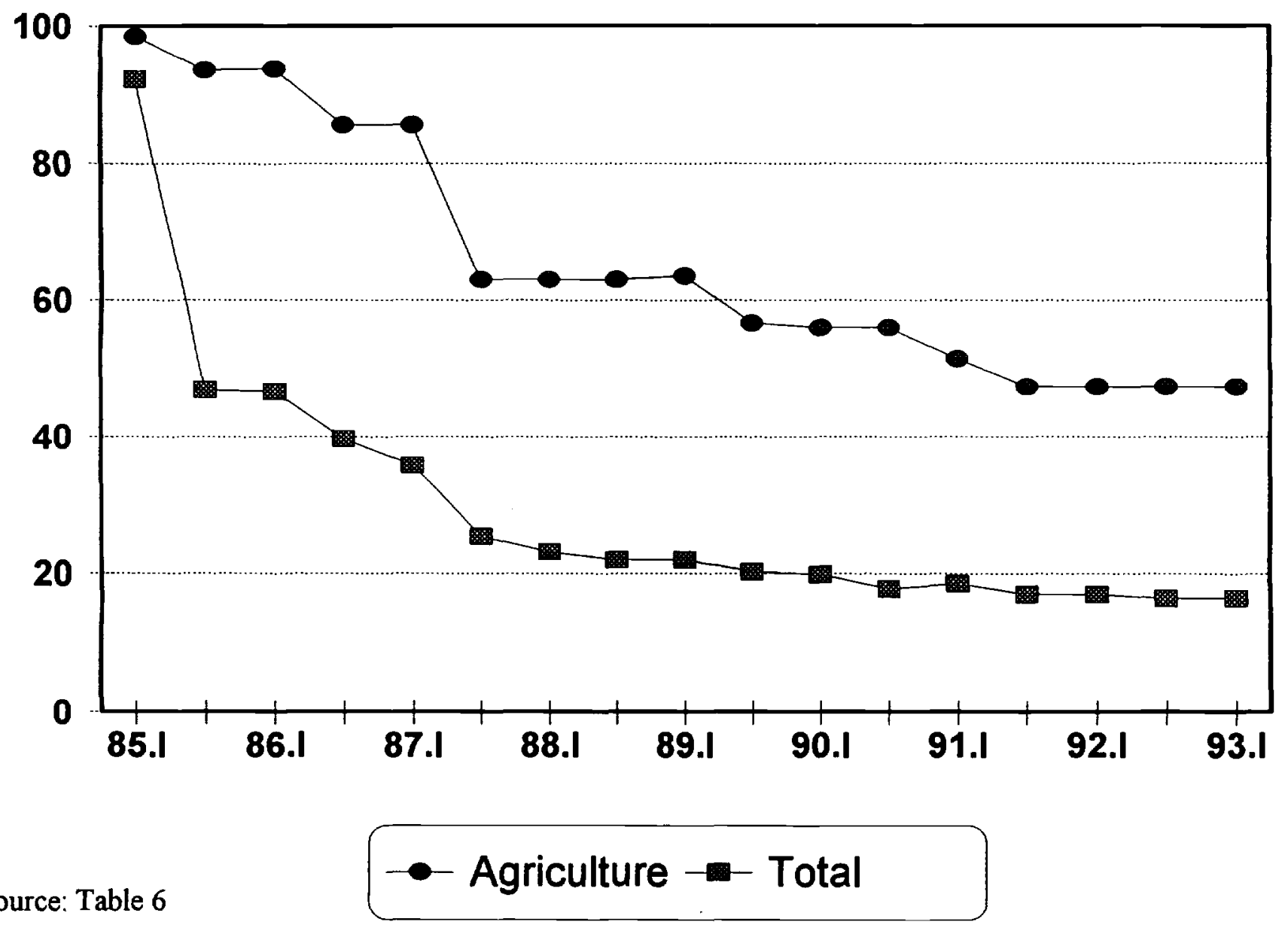


Figure 4

Average Tariff

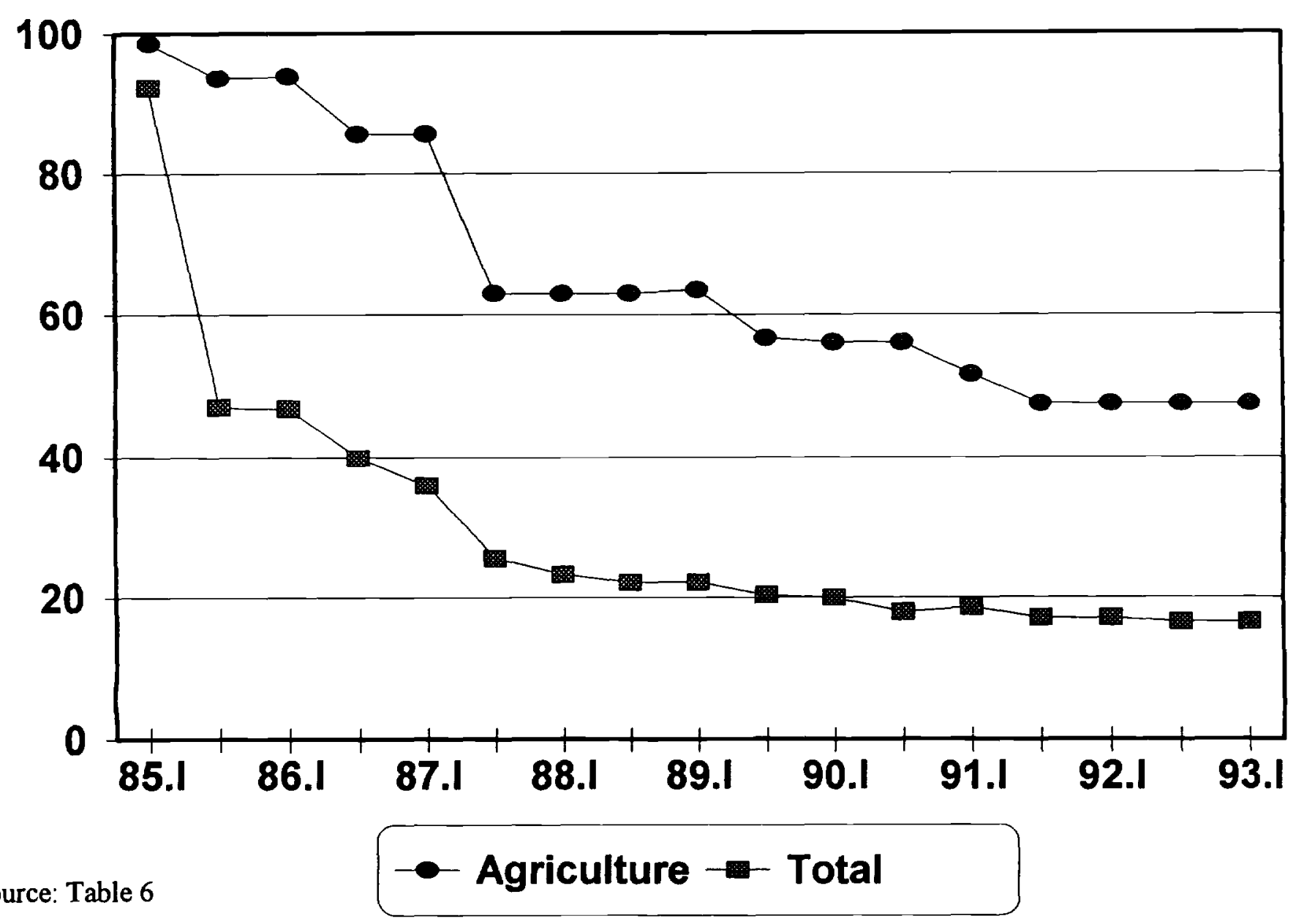


Figure 5

Import Penetration Rates

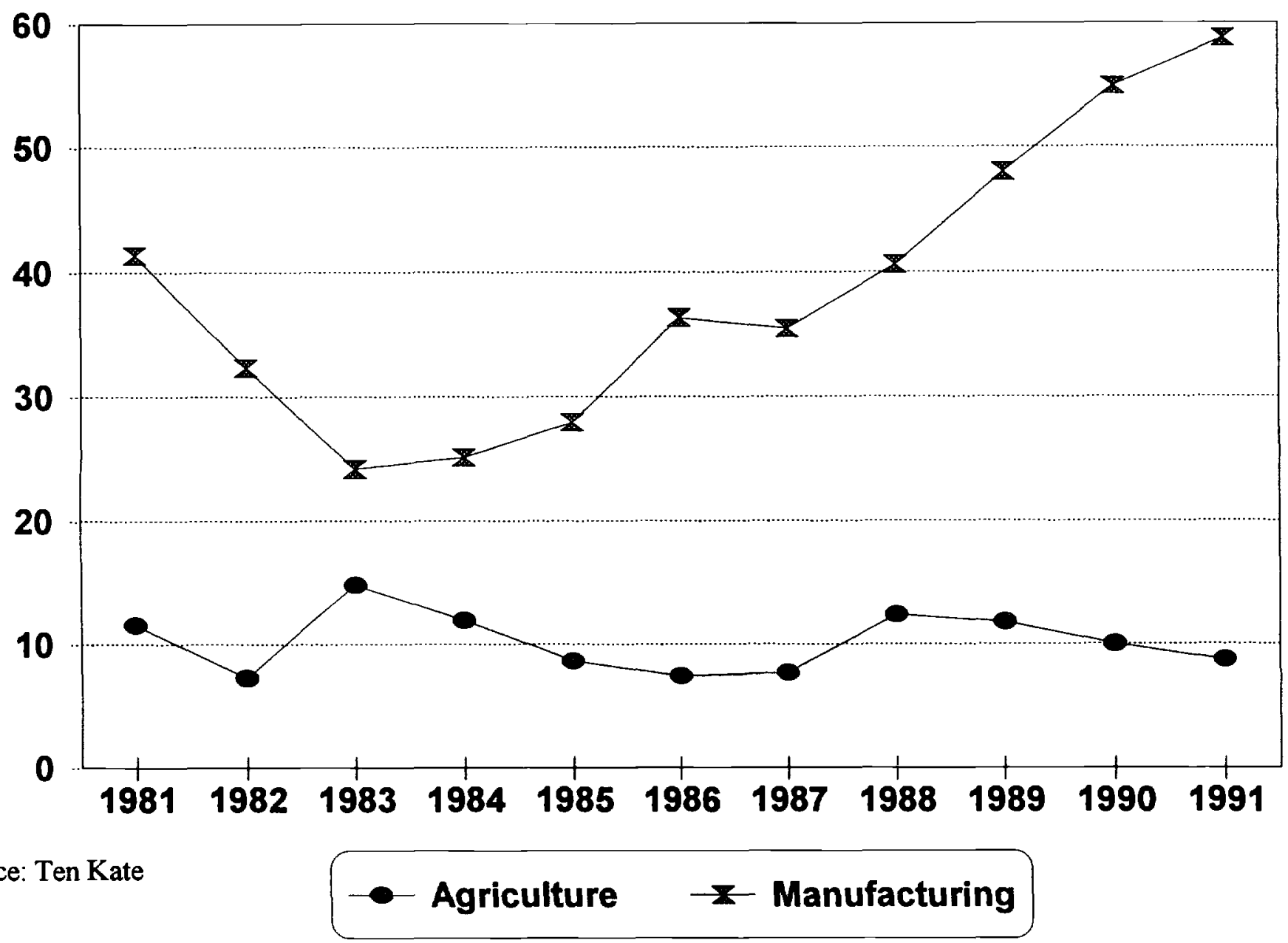


Figure 6

Exports by Type of Good

(millions of Dollars)

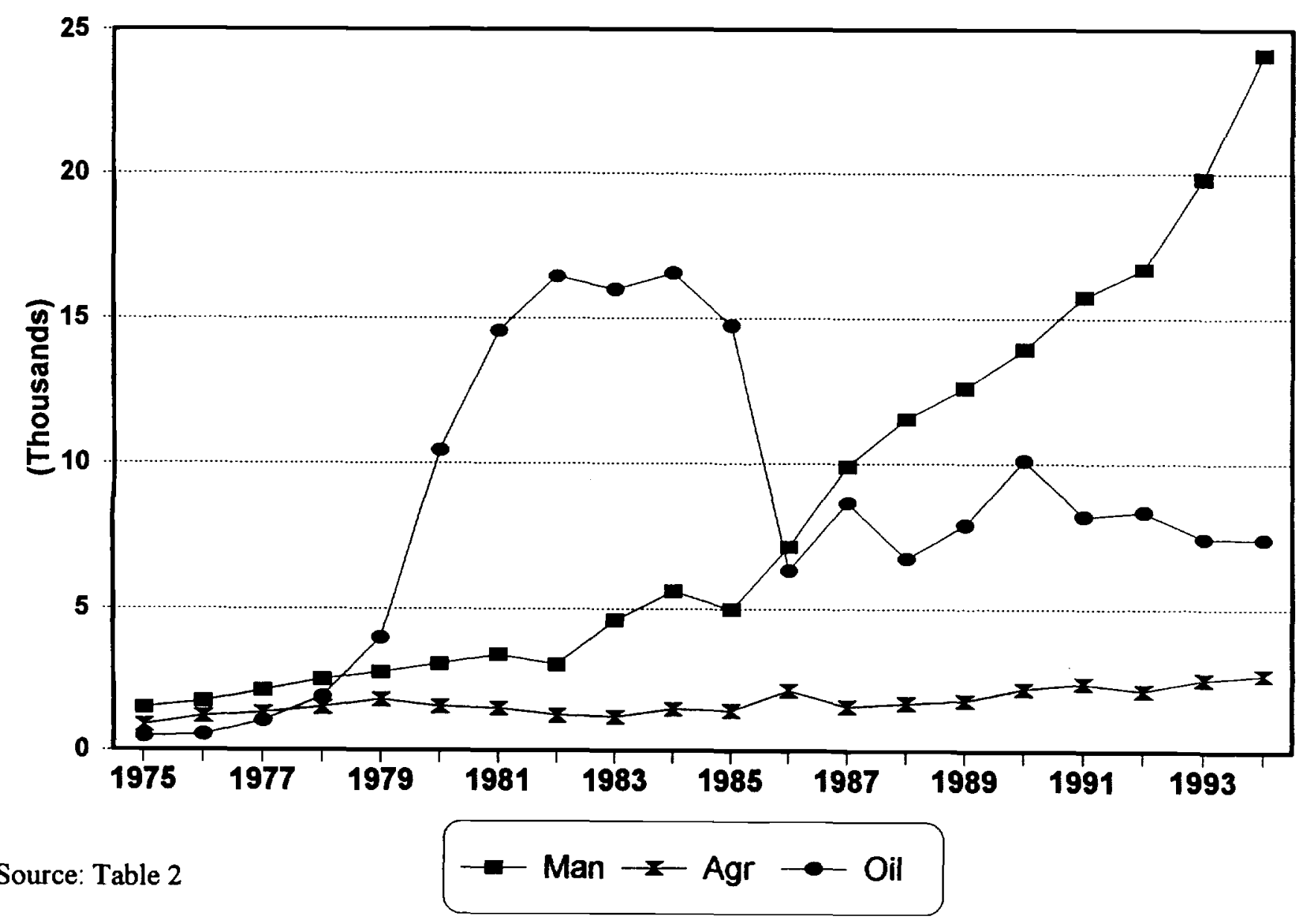


Figure 7

Imports by Type of Good

(millions of dollars)

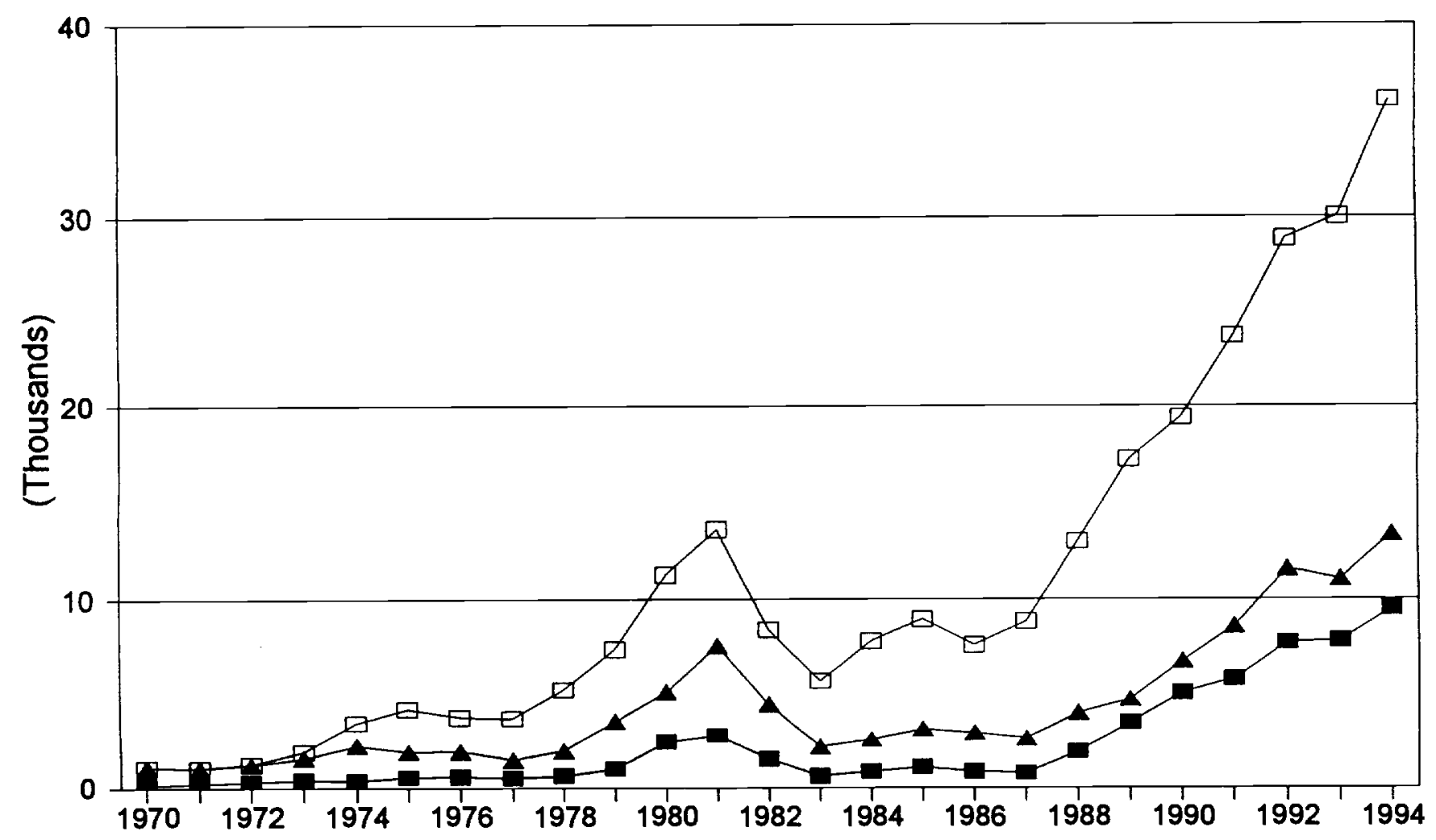

Source: Table $3 \quad-$ Consumption $\square$ Intermediate - Capital 
Figure 8a

\section{Production Volume Index}

(Relative to Overall Manufactures)

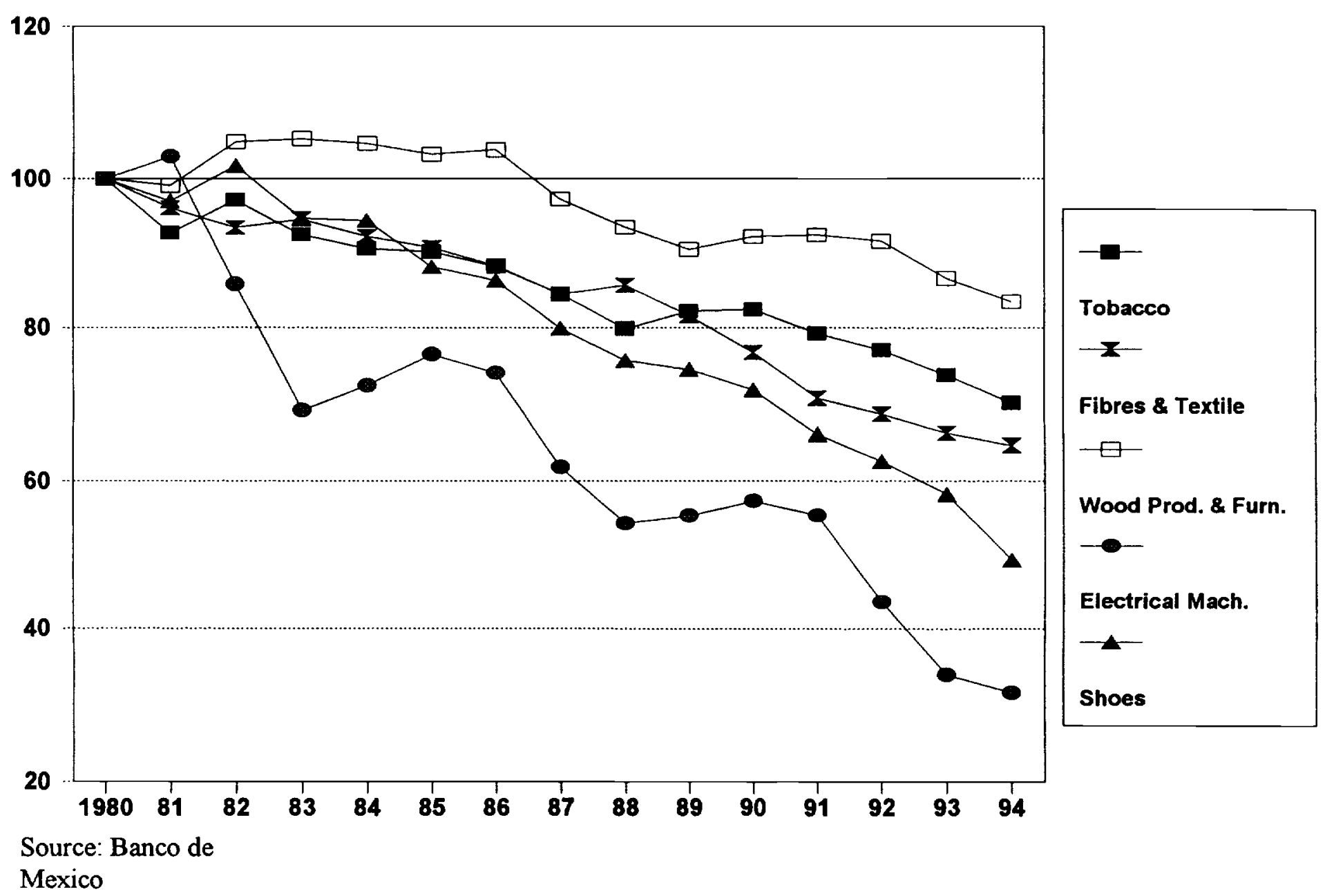


Figıre 8b

\section{Production Volume Index}

(Relative to Overall Manufactures)

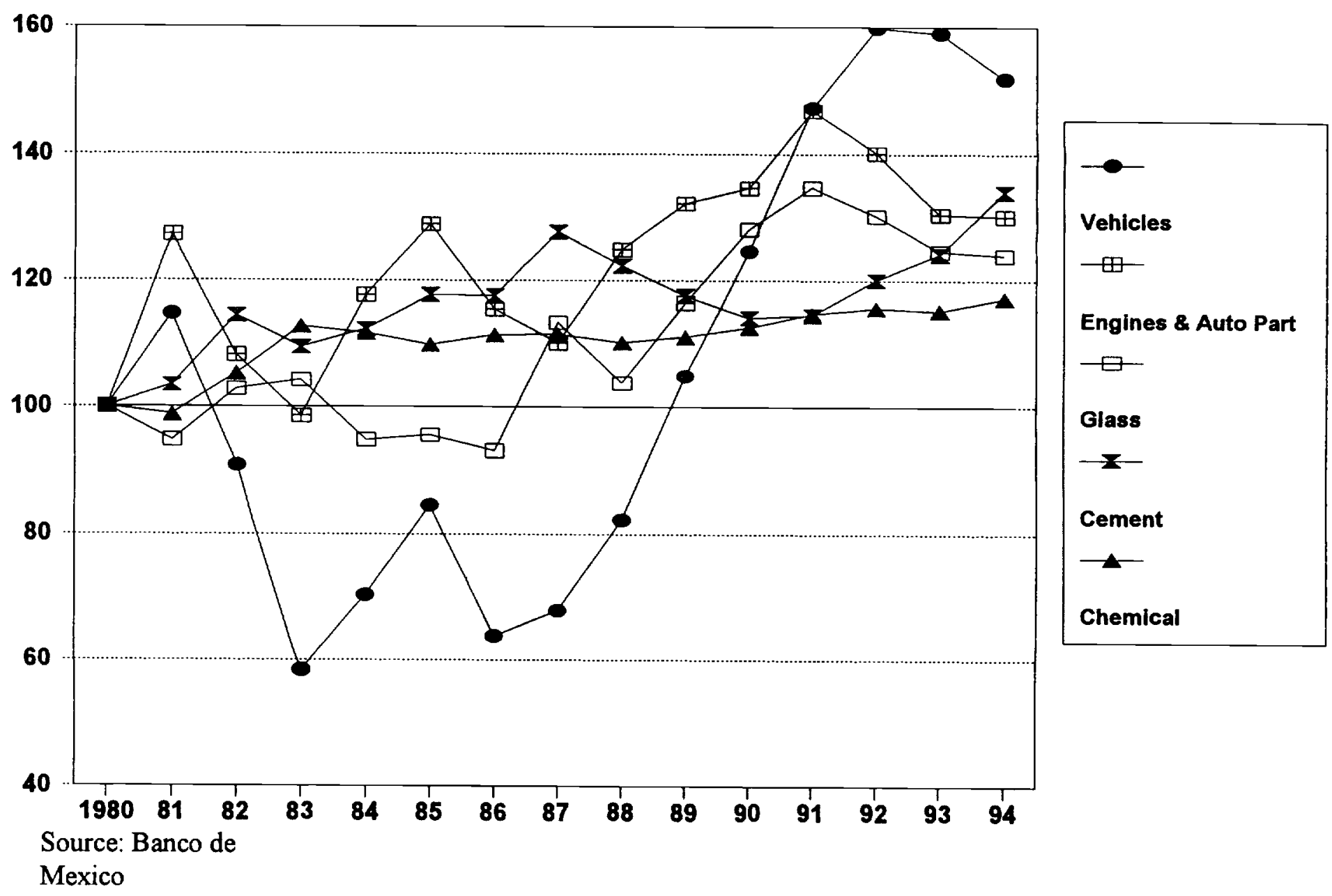


Figure 9

Mexico-USA Intraindustry Trade

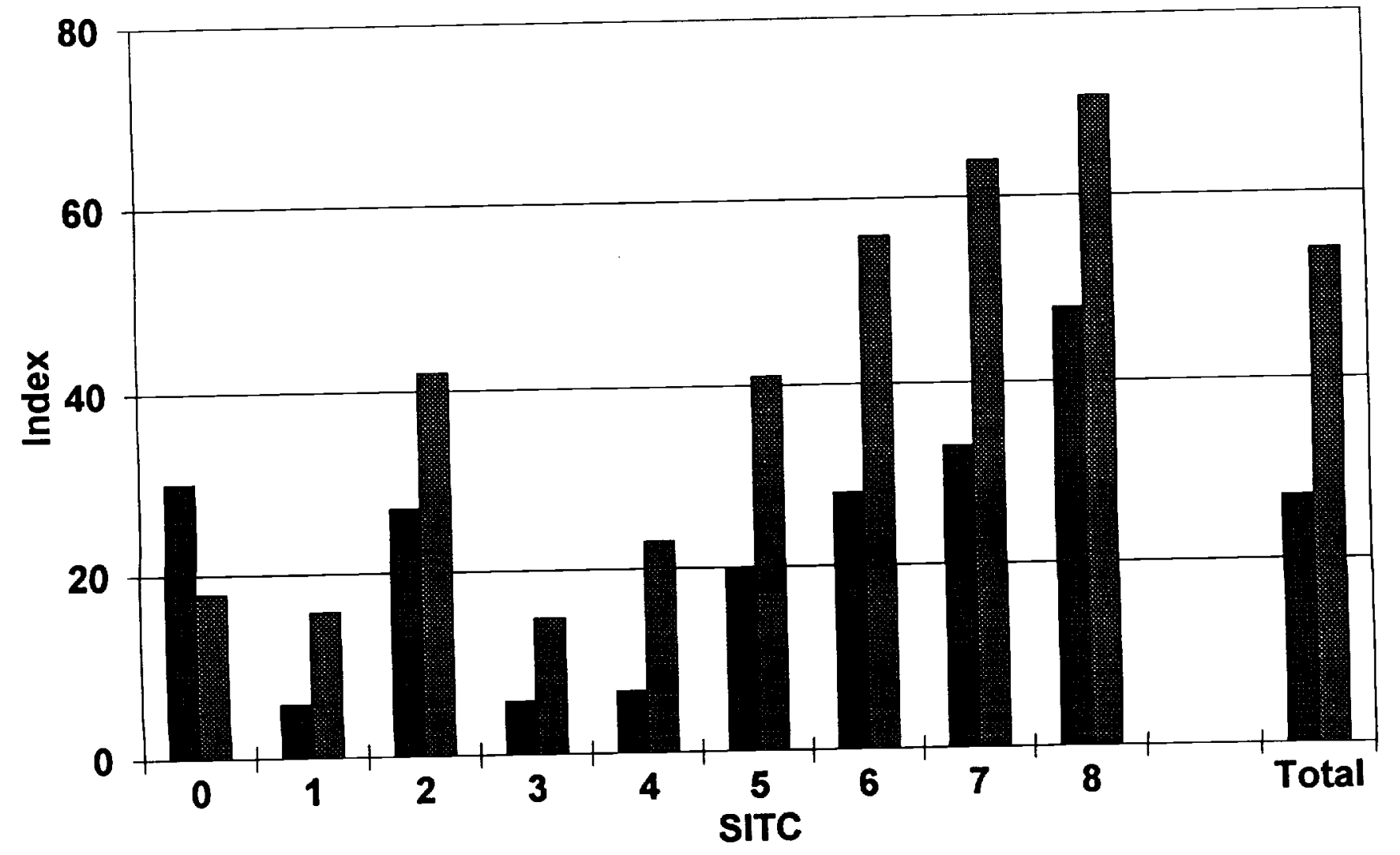

Source: Esquivel (1992). 
Figure 10

Flows of Foreign Direct Investment (millions of dollars)

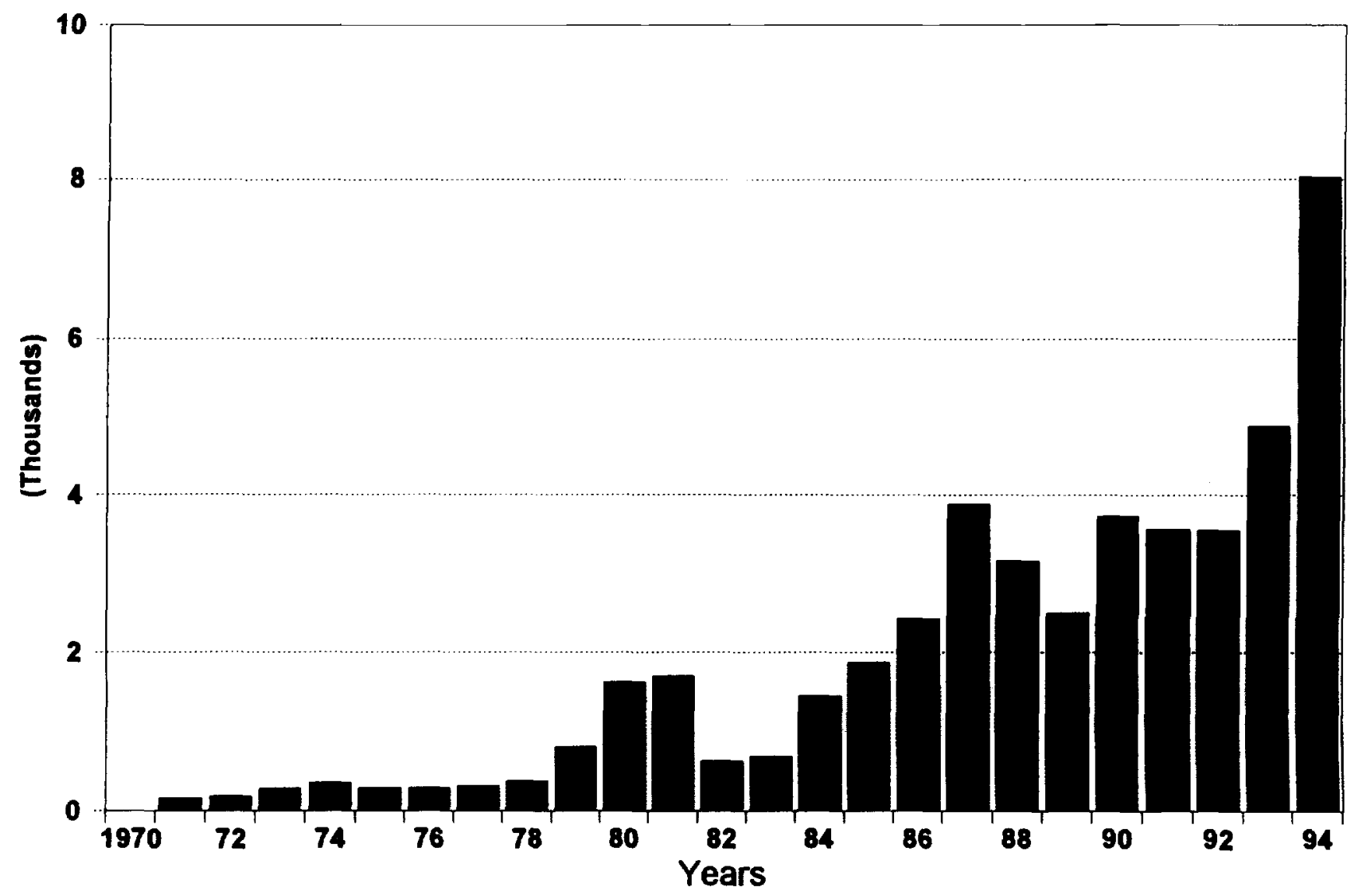

Source:Secofi 
Figure 11

Foreign Direct Investment

(Average Monthly Flow)

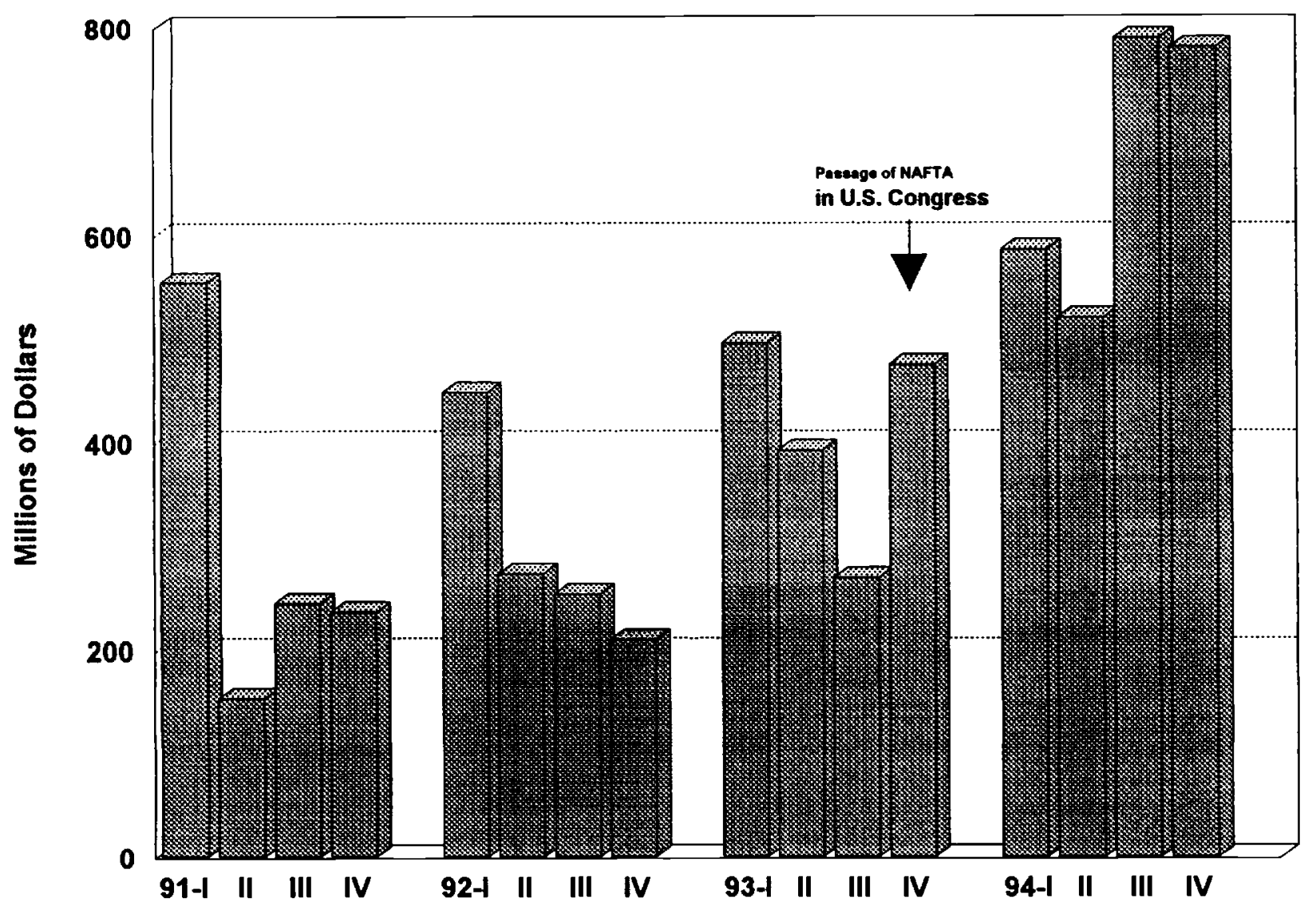

Source: Secofi 
Table 1

\section{Indicators of Protection}

\begin{tabular}{|c|c|c|c|c|c|}
\hline & $\begin{array}{l}\text { Domestic Product Covered } \\
\text { by Import Permits (\%) }\end{array}$ & $\begin{array}{l}\text { Production Weighted } \\
\text { Average Tariff }\end{array}$ & $\begin{array}{l}\text { Maximum } \\
\text { Tariff }\end{array}$ & $\begin{array}{l}\text { Imports Subject } \\
\text { to Permits }(\%)\end{array}$ & $\begin{array}{c}\text { Fractions Subject } \\
\text { to Permits }(\%)\end{array}$ \\
\hline 1980 & 64.0 & 22.8 & n.a. & n.a. & n.a. \\
\hline 1985 & 92.2 & 23.5 & 100.0 & 35.1 & 10.4 \\
\hline 1986 & 46.9 & 24.0 & 45.0 & 27.8 & 7.8 \\
\hline 1987 & 35.8 & 22.7 & 20.0 & 26.8 & 3.9 \\
\hline 1988 & 23.2 & 11.0 & 20.0 & 21.2 & 3.4 \\
\hline 1989 & 22.1 & 12.8 & 20.0 & 18.4 & 1.8 \\
\hline 1990 & 19.9 & 12.5 & 20.0 & 13.7 & 1.7 \\
\hline 1991 & 18.6 & 12.5 & 20.0 & 9.1 & 1.6 \\
\hline 1992 & 17.0 & 12.5 & 25.0 & 10.8 & 1.6 \\
\hline 1993 & 16.5 & 12.5 & 25.0 & 21.5 & 1.6 \\
\hline 1994 & n.a. & n.a. & n.a. & 10.6 & 1.3 \\
\hline
\end{tabular}

Source: $\quad$ SECOFI and Ten Kate (1993). 
Table 2

\section{Exports by Type of Good}

(millions of dollars)

\begin{tabular}{|c|c|c|c|c|c|c|c|c|}
\hline \multirow[b]{2}{*}{ Year } & \multirow[b]{2}{*}{ TOTAL } & \multicolumn{3}{|c|}{ Oil Goods } & \multicolumn{4}{|c|}{ Non Oil Goods } \\
\hline & & Total & Crude Oil & Others & Total & Agricultural & Extractives & Manufactures \\
\hline 1975 & 3,062 & 480 & 438 & 42 & 2,582 & 892 & 207 & 1,483 \\
\hline 1976 & 3,655 & 563 & 540 & 23 & 3,092 & 1,175 & 209 & 1,708 \\
\hline 1977 & 4,650 & 1,037 & 988 & 50 & 3,613 & 1,313 & 217 & 2,083 \\
\hline 1978 & 6,063 & 1,863 & 1,774 & 90 & 4,200 & 1,502 & 213 & 2,485 \\
\hline 1979 & 8,818 & 3,975 & 3,765 & 210 & 4,843 & 1,779 & 338 & 2,726 \\
\hline 1980 & 15,512 & 10,441 & 9,449 & 993 & 5,071 & 1,528 & 512 & 3,030 \\
\hline 1981 & 20,102 & 14,573 & 13,305 & 1,268 & 5,529 & 1,481 & 686 & 3,360 \\
\hline 1982 & 21,230 & 16,477 & 15,623 & 855 & 4,753 & 1,233 & 502 & 3,018 \\
\hline 1983 & 22,312 & 16,017 & 14,793 & 1,224 & 6,295 & 1,189 & 524 & 4,583 \\
\hline 1984 & 24,196 & 16,601 & 14,968 & 1,634 & 7,595 & 1,461 & 539 & 5,595 \\
\hline 1985 & 21,664 & 14,767 & 13,309 & 1,458 & 6,897 & 1,409 & 510 & 4,978 \\
\hline 1986 & 16,031 & 6,307 & 5,580 & 727 & 9,724 & 2,098 & 510 & 7,116 \\
\hline 1987 & 20,656 & 8,630 & 7,877 & 753 & 12,026 & 1,543 & 576 & 9,907 \\
\hline 1988 & 20,565 & 6,711 & 5,883 & 828 & 13,854 & 1,670 & 660 & 11,523 \\
\hline 1989 & 22,842 & 7,876 & 7,292 & 584 & 14,966 & 1,754 & 605 & 12,608 \\
\hline 1990 & 26,838 & 10,104 & 8,921 & 1,183 & 16,734 & 2,162 & 617 & 13,955 \\
\hline 1991 & 26,856 & 8,167 & 7,265 & 902 & 18,689 & 2,373 & 547 & 15,769 \\
\hline 1992 & 27,515 & 8,307 & 7,420 & 887 & 19,208 & 2,112 & 356 & 16,740 \\
\hline 1993 & 30,032 & 7,418 & 6,485 & 933 & 22,614 & 2,504 & 278 & 19,832 \\
\hline 1994 & 34,564 & 7,393 & 6,572 & 821 & 27,171 & 2,678 & 357 & 24,136 \\
\hline
\end{tabular}


Table 3

Imports by Type of Good

(millions of dollars)

\begin{tabular}{|c|c|c|c|c|}
\hline Year & TOTAL & $\begin{array}{c}\text { Consumption } \\
\text { Goods }\end{array}$ & $\begin{array}{c}\text { Intermediate } \\
\text { Goods }\end{array}$ & $\begin{array}{l}\text { Capital } \\
\text { Goods }\end{array}$ \\
\hline 1970 & $2,328.3$ & 177.8 & $1,059.0$ & $1,091.4$ \\
\hline 1971 & $2,255.5$ & 209.6 & $1,023.4$ & $1,021.0$ \\
\hline 1972 & $2,762.1$ & 304.0 & $1,253.5$ & $1,199.8$ \\
\hline 1973 & $3,892.4$ & 395.1 & $1,918.4$ & $1,563.0$ \\
\hline 1974 & $6,148.6$ & 367.5 & $3,504.7$ & $2,251.4$ \\
\hline 1975 & $6,699.0$ & 561.0 & $4,241.0$ & $1,897.0$ \\
\hline 1976 & $6,300.0$ & 564.0 & $3,806.0$ & $1,930.0$ \\
\hline 1977 & $5,704.0$ & 503.0 & $3,719.0$ & $1,482.0$ \\
\hline 1978 & $7,917.0$ & 650.0 & $5,285.0$ & $1,982.0$ \\
\hline 1979 & $11,980.0$ & $1,002.0$ & $7,404.0$ & $3,574.0$ \\
\hline 1980 & $18,897.0$ & $2,450.0$ & $11,274.0$ & $5,173.0$ \\
\hline 1981 & $23,948.0$ & $2,807.0$ & $13,566.0$ & $7,575.0$ \\
\hline 1982 & $14,437.0$ & $1,517.0$ & $8,417.0$ & $4,503.0$ \\
\hline 1983 & $8,551.0$ & 614.0 & $5,740.0$ & $2,197.0$ \\
\hline 1984 & $11,254.0$ & 848.0 & $7,833.0$ & $2,573.0$ \\
\hline 1985 & $13,212.0$ & $1,082.0$ & $8,965.0$ & $3,165.0$ \\
\hline 1986 & $11,432.0$ & 846.0 & $7,632.0$ & $2,954.0$ \\
\hline 1987 & $12,223.0$ & 768.0 & $8,824.0$ & $2,631.0$ \\
\hline 1988 & $18,898.0$ & $1,921.0$ & $12,950.0$ & $4,027.0$ \\
\hline 1989 & $25,438.0$ & $3,498.0$ & $17,171.0$ & $4,769.0$ \\
\hline 1990 & $31,272.0$ & $5,098.6$ & $19,383.8$ & $6,789.6$ \\
\hline 1991 & $38,184.1$ & $5,834.3$ & $23,762.3$ & $8,587.5$ \\
\hline 1992 & $48,192.6$ & $7,744.1$ & $28,892.8$ & $11,555.7$ \\
\hline 1993 & $48,923.6$ & $7,842.4$ & $30,025.3$ & $11,055.9$ \\
\hline 1994 & $58,881.4$ & $9,511.0$ & $36,048.6$ & $13,321.8$ \\
\hline
\end{tabular}

Nole: Do not include imports from maquiladoras.

Source: Banco de Mexico. 


\section{Manufacturing Industry by Type of Trade with US}

\begin{tabular}{|crr|}
\hline & 1981 & 1990 \\
\hline Intraindustry Trade & & \\
Number of Sectors & 46 & 82 \\
Share of Total Exports (\%) & 48.8 & 72.3 \\
Share of Total Imports (\%) & 19.8 & 70.7 \\
Share of Foreign Trade (\%) & 27.3 & 71.4 \\
& & \\
Interindustry Trade & 104 & 84 \\
Number of Sectors & 51.2 & 27.7 \\
Share of Total Exports (\%) & 80.2 & 29.3 \\
Share of Total Imports (\%) & 72.7 & 28.6 \\
Share of Foreign Trade (\%) & & \\
& & \\
\hline
\end{tabular}

Source: Esquivel (1992)

Note: Sectors with a Grubel and Lloyd index of Intraindustry trade above $50 \%$ are considered to have intraindustrial trade. The Grubel and Lloyd index is defined as $B i=1-(|X i-M i|) /(X i+M i)$, where $X i$ and $M i$ are exports and imports of sector $\mathrm{i}$. 
Table 5

Manufacturing Industry Protection

\begin{tabular}{|c|c|c|c|c|}
\hline \multirow[t]{2}{*}{ Industry } & \multicolumn{2}{|c|}{$\begin{array}{l}\text { Output Protected by } \\
\text { Import Permits (\%) }\end{array}$} & \multicolumn{2}{|c|}{ Average Tariff Rates (\%) } \\
\hline & 1985 & 1990 & 1985 & 1990 \\
\hline Food & 95.2 & 19.7 & 20.3 & 11.3 \\
\hline Beverages & 99.6 & 2.6 & 84.7 & 19.6 \\
\hline Tobacco & 100.0 & 100.0 & 50.0 & 20.0 \\
\hline Textiles & 90.8 & 1.0 & 34.1 & 15.0 \\
\hline Apparel & 100.0 & 0.0 & 49.8 & 20.0 \\
\hline Footwear & 97.8 & 0.0 & 42.6 & 16.2 \\
\hline Wood & 99.9 & 0.0 & 38.3 & 16.9 \\
\hline Paper and Printing & 85.6 & 0.0 & 26.2 & 8.7 \\
\hline Basic Chemicals & 81.2 & 1.5 & 30.5 & 13.6 \\
\hline Tires and Plastics & 98.2 & 0.0 & 36.5 & 15.8 \\
\hline Glass & 96.9 & 0.0 & 52.7 & 16.5 \\
\hline Cement & 100.0 & 0.0 & 10.0 & 10.0 \\
\hline Non-met. Minerals & 93.4 & 0.0 & 36.9 & 16.5 \\
\hline Iron and Steel & 90.7 & 0.0 & 13.4 & 10.1 \\
\hline Non-ferrous Metals & 71.9 & 0.0 & 22.2 & 12.4 \\
\hline Metal Products & 72.4 & 1.1 & 35.9 & 14.5 \\
\hline Electrical Equipment & 79.8 & 3.1 & 21.0 & 15.6 \\
\hline Non-Electrical Equipment & 97.1 & 0.0 & 32.9 & 17.1 \\
\hline Transportation Equipment & 99.3 & 37.6 & 41.1 & 16.0 \\
\hline
\end{tabular}

Source: Tybout and Westbrook (1995) 
Table 6

Protection in the Agriculture Sector

\begin{tabular}{|c|c|c|c|c|}
\hline & \multicolumn{2}{|c|}{$\begin{array}{l}\text { Output Covered by } \\
\text { Import Permits (\%) }\end{array}$} & \multicolumn{2}{|c|}{ Average Tariff Rates (\%) } \\
\hline & Agriculture & Total & Agriculture & Total \\
\hline 85.1 & 98.5 & 92.2 & 7.6 & 23.5 \\
\hline 85.II & 93.5 & 47.1 & 7.7 & 28.5 \\
\hline 86.1 & 93.8 & 46.9 & 7.4 & 24.0 \\
\hline 86.11 & 85.6 & 39.8 & 9.6 & 24.5 \\
\hline 87.1 & 85.6 & 35.8 & 10.0 & 22.7 \\
\hline 87.11 & 63.0 & 25.4 & 6.0 & 11.8 \\
\hline 88.1 & 63.0 & 23.2 & 6.0 & 11.0 \\
\hline 88.II & 63.0 & 22.1 & 5.8 & 10.2 \\
\hline 89.1 & 63.5 & 22.1 & 8.2 & 12.6 \\
\hline 8911 & 56.7 & 20.3 & 8.2 & 12.5 \\
\hline 90.1 & 56.1 & 19.9 & 8.2 & 12.5 \\
\hline 90.11 & 56.1 & 17.9 & 7.4 & 12.4 \\
\hline 91.1 & 51.6 & 18.6 & 7.4 & 12.5 \\
\hline 91.11 & 47.6 & 17.0 & 7.5 & 12.5 \\
\hline 92.1 & 47.6 & 17.0 & 7.5 & 12.5 \\
\hline 92.11 & 47.6 & 16.5 & 7.5 & 12.5 \\
\hline 93.1 & 47.6 & 16.5 & 7.5 & 12.5 \\
\hline
\end{tabular}

Source: Unpublished infomation provided by Adrian Ten Kate. 